GEFAD / GUJGEF41(2): 817-854(2021)

\title{
Montessori Yöntemine Nörobilimsel Bakış Açısı: Disiplinler Arası İnceleme*
}

\section{Neuroscientific Perspective on the Montessori Method: An Interdisciplinary Investigation}

\author{
Şeyma Sultan BOZKURT ${ }^{1}$, İlkay ULUTAŞ ${ }^{2}$ \\ 'İnönü Üniversitesi, Temel Ĕ̆itim Bölümü, Okul Öncesi Ĕ̌itimi Ana Bilim Dall. \\ seyma.bozkurt@inonu.edu.tr \\ ${ }^{2}$ Gazi Üniversitesi, Temel Ĕgitim Bölümü, Okul Öncesi Eğitimi Ana Bilim Dall. \\ uilkay@gazi.edu.tr
}

Makalenin Geliş Tarihi: 15.02.2021

Yayına Kabul Tarihi: 20.05.2021

$\ddot{O} Z$

Yüzyılı aşkın süredir dünyanın birçok ülkesinde uygulanmakta olan Montessori yöntemi çocukların gelişim ve ögrenmesinin erken yıllardan itibaren özel hazırlanmış bir ortam ve çocuk merkezli yaklaşımlar ile desteklenmesini, çocuğun bağımsız birey olmasını hedefleyen bir eğitim yaklaşımıdır. Bu araştırmada eğitim ve nörobilim iliş̧kisinden yola çıkılarak, Montessori eğitim yönteminde yer alan temel özelliklerin nörobilimsel bakış açısı ile açıklanması, Montessori ve nörobilimin ilişkilendirildiği araştırmaların incelenerek disiplinler arası bir bakış açısı ortaya konulması amaçlanmıştır. Araştırma, derleme türünde planlanmış nitel bir araştırmadır. Verilerin toplanmasında doküman analizi tekniği kullanılarak iki tarama aşaması ile dokümanlara ulaşılmıştır. İlk taramada Montessori yöntemi ile nörobilimsel çalışmaların iliş̧kilendirildiği çalı̧̧malar incelenerek Montessori yönteminin "Hassas Dönemler", "Yapılandırılmış Ortam", "Duyu Eğitimi", "Tekrarla Kendiliğinden Öğrenme", "Dil-Beyin" ve "Hareket-Beyin" gibi özelliklerinin nörobilim ile ilişkilendirildiği tespit edilmiştir. İkinci taramada ise Montessori ve nörobilim çalışmalarında bu özelliklerin nasıl açıklandĭ̆ incelenmiştir. Araştırma bulguları, Montessori'nin çocuk gelişimi ve öğrenmesine iliş̧kin oluşturduğu özelliklerin yıllar sonra nörobilim alanında yapılan araştırma bulgular ile de desteklendiğini göstermiştir.

Anahtar Sözcükler: Maria montessori, Montessori yöntemi, Nörobilim, Beyin ve öğrenme, Erken çocukluk eğitimi.

\footnotetext{
* Alıntılama: Bozkurt, S. S. ve Ulutaş, İ. (2021). Montessori Yöntemine Nörobilimsel Bakış Açısı: Disiplinler Arası İnceleme. Gazi Üniversitesi Gazi Eğitim Fakültesi Dergisi, 4l(2), 817854.
} 


\section{ABSTRACT}

The Montessori method, which has been applied in many countries of the world for more than a century, is an educational approach that aims to support the development and learning of children from early years with a specially prepared environment and child-centered approaches, and that the child becomes an independent individual. In this study, based on the relationship between education and neuroscience, it is aimed to explain the basic features of the Montessori education method with a neuroscientific perspective, and to reveal an interdisciplinary perspective by examining the studies that associate Montessori and neuroscience. This research is a qualitative research planned in the type of review. The documents were reached in two scanning stages by using the document analyses technique in the collection of data. In the first screening, the studies that associate the Montessori method with neuroscientific studies were examined, and it was determined that the characteristics of the Montessori method such as "Sensitive Periods", "Structured Environment", "Sensory Education", "Repeat Self-Learning", "Language-Brain" and "Movement-Brain" were associated with neuroscience. In the second screening, how these features were explained in Montessori and neuroscience studies was examined. Research findings have shown that the characteristics of Montessori regarding child development and learning are supported by the research findings in the field of neuroscience after years.

Keywords: Maria montessori, Montessori method, Neuroscience, Brain and learning, Early childhood education

\section{GİRiş}

Duyu temelli öğrenme pedagojisi ile bilinen Montessori eğitim yöntemi çocuğu gözlemek, kendi performansını ortaya koymasını, kendi hızında öğrenmesini sağlamak amacıyla Maria Montessori tarafından geliştirilmiştir (Lopata, Wallace ve Finn, 2005; Poussin, 2015). Maria Montessori tüm müdahale ve engellemelere rağmen zamanının kadınlar için daha onaylanmış ve kabul edilebilir meslekleri yerine tıp alanında öğrenimini tamamlamış (Catherine, Javier ve Francisco, 2020; Sackett, 2016), asistanlığı sırasında zihinsel yetersizliği olan çocuklarla yaptığı gözlemleri onu eğitim alanına doğru yöneltmiştir. $\mathrm{Bu}$ çocuklar ile çalışırken bazı davranışları gösterememelerinin nedeninin zihinsel yetersizlikler olmadığını, çevrelerindekinden gerekli ilgiyi görmedikleri için hastanede olduklarını, deneyime ihtiyaç duyduklarını, çevrelerinde dokunup hissedebilecekleri herhangi bir şey olduğunda gelişimlerini ortaya koyabileceklerini belirlemiştir (Çakıroğlu Wilbrant, 2019, s. 17). Yapmış olduğu bu gözlemlerle Montessori, sadece beyinle değil tüm gelişim alanları ile çocuğu ele almış, 
bilimin insan ruhunu insan zihnine/beynine indirgeme hatasından kaçınmıştır (Regni'den aktaran Sackett, 2016). Deneyimleri doğrultusunda çocuklar için düzen ve özgürlük arasında mantıklı bir denge oluşturarak kendi adıyla anılan "Montessori Eğitim Yaklaşımı"nı oluşturmuştur. Montessori yaklaşımı çocuklara doğal gereksinimlerini karşılayan özenle yapılmış materyallerle zenginleştirilmiş özgür ve huzurlu bir ortamı içerir. Bu zengin ortama iyi eğitim almış, gözlem becerisi yüksek öğretmen rehberlik eder (Lillard, 2020; Lillard vd., 2017). Eğitim sürecinde çocukların ilgi ve ihtiyaçları temel alınır, gelişim ve öğrenmeleri duyusal materyaller ile desteklenir.

Geçmişten günümüze yapılan birçok araştırma çocuğu merkeze alması, bütüncül gelişimini desteklemesi ve tüm performansını ortaya koymasına imkân vermesi bakımından montessori eğitiminin etkili sonuçlarını ortaya koymaktadır (Acay, 2018; Bezirci,2017; Bülgür, 2018; Canbulat Zengin, 2019; Dedeoğlu, 2018; Dinçer Yavuz, 2019; Durkaya, 2019; Kınık, 2018; Lillard, 2020; Lillard vd., 2017; Noyat, 2018; Oğuz ve Köksal Akyol, 2006; Sackett, 2016; Şimşek, 2018; Tomele ve Lidaka, 2017; Üstündağ, 2019; Yıldırım, 2019; Yıldız, 2018). Yaklaşımın bu etkisi felsefesinin temellerinin gözlemler ve deneysel çalışmalarla oluşturulmasına bağlanmaktadır. Eğim felsefesinde erken yıllarda çocukların gelişimlerinde kritik öneme sahip olan hassas dönemler, emici zihin, duyu eğitimi, hazırlanmış ortam, kendiliğinden öğrenme, dilbeyin, hareket-beyin ilişkisi gibi özellikler vurgulanmaktadır. $\mathrm{Bu}$ özellikler çocuğun gelişimi ve öğrenmesini açıkladığından nörobilim açısından da vurgulanan özelliklerdir. Nörobilimde henüz bu konularla ilgili olarak detaylı keşifler yapılmadığı süreçte, Montessori, bu özelliklere dayalı eğitim yöntemi tasarlamış ve uygulamıştır (Catherine, Javier ve Francisco, 2020; Fabri ve Fotuna, 2020; Sackett, 2016). Dolayısıyla Montessori yönteminin beyin açısından da güçlü bağlantılarının olacağı düşünülmüştür. Nöroloji, psikoloji ve biyolojiyi kapsayan nörobilim, moleküler ve hücresel seviyelerden beyin sistemlerine kadar beynin öğrenme ve hatırlama süreçlerini açıklayan bir bilim alanıdır (Goswami, 2004). Nörobilimdeki gelişmeler eğitim için de önemli katkılar sağlar. Çünkü öğrenmenin temelini oluşturan süreçleri anlama, biyolojik ve çevresel koşullardaki engellerin üstesinden gelme, bireysel farklılıkları ve 
nedenlerini ortaya koyma, ortam, bağlam gibi koşullara göre öğrenmeyi geliştirme gibi birçok açıdan kanıtlar sunar. Böylelikle nörobilimde elde edilen kanıtlar sadece bilimsel açıdan ilgi çekici ve değerli olmakla kalmaz, aynı zamanda, öğrenme mekanizmalarının tam olarak anlaşılması bakımından eğitim için de felsefe, yaklaşım, uygulama hatta politikaları biçimlendirecek kanıtlar ortaya koyar (Goswami, 2011; Olson \& Hergenhahn, 2016, s. 343-344).

Montessori yöntemi ve nörobilim çalışmalarının ortak özelliğini erken yıllarda gelişim ve öğrenmenin önemi oluşturmaktadır. Nörobilim alanında yapılan araştırmalarda (Campbell, 2011; van der Meulen, Krabbendam \& de Ruyter, 2015; van Dijk \& Lane, 2020; Rosenberg-Lee, 2018) erken çocukluk döneminde beyin gelişiminin önemine dikkat çekilmekte ve bu dönemdeki müdahalelerin bilişsel gelişim üzerindeki katkılarına odaklanılmaktadır (Akdağ, 2015). Yüzyılı aşkın süredir dünyanın birçok ülkesinde uygulanmakta olan Montessori yöntemi de okul öncesi çocuklarının gelişim ve öğrenmesinin özel hazırlanmış bir ortam ve çocuk merkezli yaklaşımlar ile desteklenmesini, çocuğun bağımsız birey olmasını hedefler. Bu doğrultuda araştırmada, “Montessori Yönteminin hangi özellikleri nörobilim alanında yapılan beyin ve öğrenme ile ilgili keşiflerle desteklenmektedir?” sorusundan yola çıkılarak Montessori eğitim yönteminde yer alan temel özelliklerin nörobilimsel bakış açısı ile açıklanması, Montessori ve nörobilimin ilişkilendirildiği araştırmaların incelenerek disiplinler arası bir bakış açısı ortaya konulması amaçlanmıştır.

\section{YÖNTEM}

Montessori eğitiminin özelliklerinin nörobilimsel çalışmalarla incelenmesini ve ilişkilerinin açıklanmasını amaçlayan bu nitel araştırma derleme türünde planlanmış, Montessori ve nörobilim ilişkisini içeren kaynaklara ulaşılıp analiz edilerek konuya açıklık getirilmeye çalışılmıştır. Araştırmalara ulaşılmasında ve analizinde doküman analizi tekniğinden yararlanılmıştır. Doküman analizi, araştırılmak istenen olgu ya da olgular ile ilgili bilgileri kapsayan yazılı materyallerin analiz edilmesidir (Yıldırım ve Şimşek, 2016, s.189). Doküman incelemesinde dokümanlara ulaşma, orijinalliğini 
kontrol etme, dokümanları anlama, veriyi analiz etme ve veriyi kullanma olmak üzere 5 aşama izlenmiştir (Yıldırım ve Şimşek, 2016, s. 194). Çalışma grubu, veri toplama süreci ve verilerin analizi dokuman analizi aşamalarına uygun olarak aşağıdaki şekilde gerçekleştirilmiştir:

Dokümanlara Ulaşma: Araştırmada birinci tarama çalışması ve ikinci tarama çalışması olmak üzere iki aşamada dokümanlara ulaşılmıştır. Birinci taramada; Montessori ve nörobilim arasındaki ilişkiyi doğrudan inceleyen 2017-2020 yılları arasında yapılmış olan ve Kasım 2020- Ocak 2021 tarihleri arasında ulaşılan araştırma makaleleri ve ulusal tez kaynakları taranmıștır. Montessori ve nörobilimin ilişkilendirilmesine yönelik çalışmalar son yıllarda gündeme gelen güncel bir konu olduğu için kaynak taraması bu yıllar arasında sınırlandırılmıştır. Elde edilen kaynaklar analiz edilerek ilgili konu başlıkları belirlenmiştir. Ikinci taramada ise; birinci taramadan elde edilen özelliklerin açıklanması amacıyla bu özelliklere ilişkin hem Montessori hem de nörobilim alanında 1994-2020 yılları arasında yapılmış çalışmalar incelenmiştir.

Birinci tarama çalışması: İlk olarak ERIC, Taylor \& Francis ve Web Of Science veri tabanlarında "Montessori and Neuroscience" anahtar kelimeleri ile araştırma yapılmıştır. İlk olarak zaman sınırlaması yapılmadan ERIC'te 1995-2020 yılları arasında altı adet çalışma elde edilmiştir. Bu çalışmaların birisinde (Catherine, Javier ve Francisco, 2020) Montessori ve nörobilimin doğrudan ilişkilendirildiği, diğer çalışmalarda ise (Jones, 2005; Liston,1995; Nutbrown, 2005; Sackett,2016; Smith, 2014) ilişkilendirme yapılmadığı belirlenmiştir. Taylor \& Francis’te aynı anahtar kelimeler ile yapılan taramada herhangi bir çalışmaya ulaşılamazken, Web of Science'da sekiz adet çalışmaya ulaşılmıştır. Bu çalışmalardan üçünün doğrudan Montessori ve nörobilimi ilişkilendirdiği görülmüştür (Catherine, Javier ve Francisco, 2020; Fabri ve Fortuna, 2020; Tomele ve Lidaka, 2017). Bir çalışmanın Waldorf yaklaşımı ile nörobilimi ilişkilendirdiği (Mavrelos ve Daradoumis, 2020), diğer dört çalışmada ise ilgili alanların birlikte ele alınmadı̆̆ 2020; Lamrani ve Abdelwahed, 2018; Lamrani, Abdelwahed, Chraibi, 2018; Nabar, Algieri, Tornese, Ferrante, Broffman \& Algieri, 2020). Google Scholar'da yapilan 
taramalarda "Montessori and Neuroscience" anahtar kelimesinin yanı sıra "Montessori ve Nörobilim" anahtar kelimesi de kullanılarak Web of Science'da yapılan taramada da ulaşılan iki çalışmaya (Catherine, Javier ve Francisco, 2020; Fabri ve Fortuna, 2020) ulaşılmıştır. Web of Science verilerine göre Montessori ve nörobilimin ilişkilendirildiği araştırmalar 2017-2020 yılları arasında yapılmıştır. Bu nedenle birinci tarama çalışmasına 2017-2020 yılları arasında yapılmış olan araştırmalarla devam edilmiştir. Lisansüstü ulusal tez çalışmalarına, Yüksek Öğretim Kurulu Başkanlığı (YÖK) Ulusal Tez Merkezinde "Montessori" anahtar kelimesi ile 2017-2020 yılları arasında yapılmış olan lisansüstü tezler taranmış ve 47 adet teze ulaşılmıştır. Daha sonra tarama "sosyal" grubuna ve "eğitim ve öğretim" konusuna göre sınırlandırılmış ve toplam 32 adet lisansüstü teze ulaşılmıştır. Ancak bu tezlerin içerikleri incelendiğinde Montessori Yöntemi ile nörobilimin ilişkilendirildiği çalışma tespit edilmemiştir. $\mathrm{Bu}$ nedenle lisansüstü tezler dokuman analizinden çıkarılmıştır. TR Dizin veri tabanında ise "Montessori” anahtar kelimesi ile 2017-2020 yılları arasında yapılmış olan araştırmalar taranmış ve 21 adet araştırmaya ulaşılmıştır. Daha sonra "Nörobilim" anahtar kelimesi ile 2017-2020 yılları arasında yapılmış olan 12 adet araştırmaya, "Sinirbilim" anahtar kelimesi ile 2017-2020 yılları arasında yapılmış olan 25 adet araştırmaya ulaşılmıştır. $\mathrm{Bu}$ araştırmalar incelendiğinde Montessori Yöntemi ile nörobilimi ilişkilendiren bir araştırma tespit edilmemiştir. "Montessori ve Nörobilim", "Montessori ve Sinirbilim" kelime grupları kullanıldığında ise herhangi bir araştırmaya ulaşılmamıştır.

Birinci aşama taramada "Montessori", "Nörobilim", "Sinirbilim", "Montessori ve Nörobilim" ve "Montessori and Neuroscience" anahtar kelime ve kelime grupları kullanılmıştır. Birinci aşamada incelenen çalışmalar ve bu çalışmaların nasıl seçildiğine ilişkin işlem basamaklarını gösteren tarama şeması Şekil 1'de gösterilmiştir. 

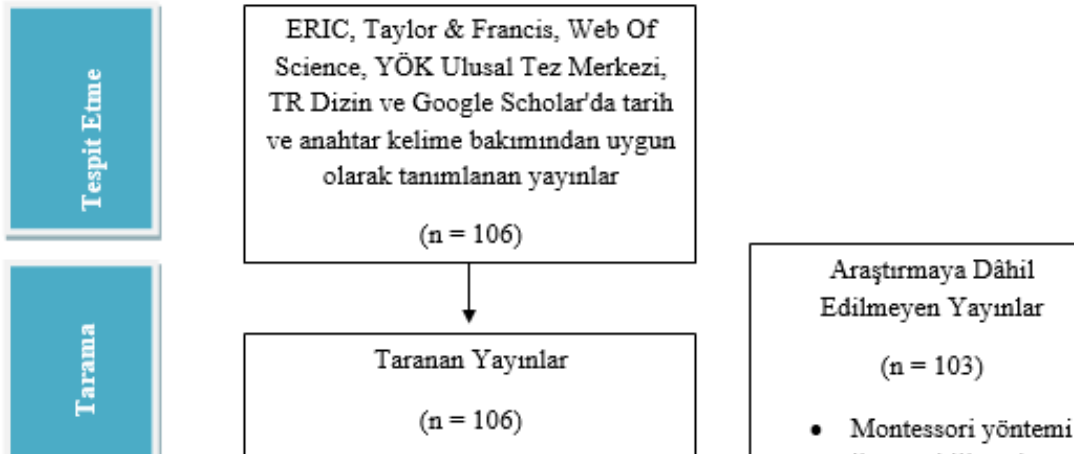

Araştırmaya Dâhil Edilmeyen Yayınlar $(\mathrm{n}=103)$

- Montessori yöntemi
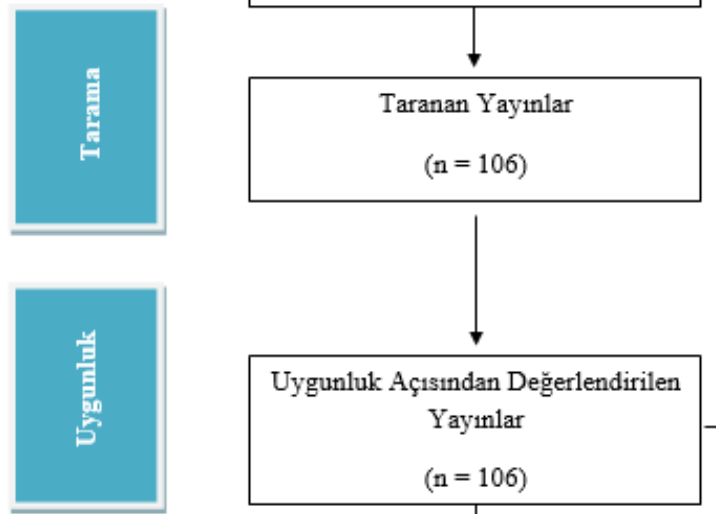

Uygunluk Açısından Değerlendirilen Yayinlar

( $\mathrm{n}=106)$
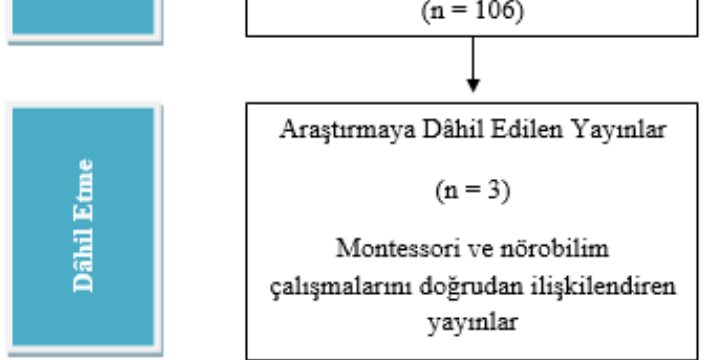
ile nörobilimsel çalışmaların birlikte ele alınmadiğ 1 lisansüstü yayınlar $(\mathrm{n}=35)$

- Nörobilim/Sinirbilim alan1 ile Montessori

Yönteminin ilişkilendirilmediği yayinlar $(n=68)$

Şekil 1. Birinci Aşamada Yapılan Tarama Sürecini İçeren Akış Şeması (Moher,

Liberati, Tetzlaff, Altman, 2009)

Şekil 1'deki tarama sürecini içeren akış şemasında görüldüğü gibi Montessori yöntemi ile nörobilimin doğrudan ilişkilendirildiği üç çalışmaya ulaşılmıştır. Konu ile ilgili yapılmış fazla çalışma olmadığı ve özellikle yurtiçinde Montessori ve nörobilimin ilişkilendirilmesine yönelik çalışmaya ulaşılmamıştır. Elde edilen bu kaynaklar analiz edilerek Montessori ve nörobilimi ilişkilendirdikleri özellikler ortaya konulmaya çalışılmıştır. Bu özellikler bulgular bölümünde Tablo 1'de verilmiştir. 
İkinci tarama çalışması: Bu aşamada birinci aşamada belirlenen temel konu başlıklarına göre her iki alanda ayrı ayrı yapılmış ve tartışma bölümünde kullanılacak olan araştırmaların derlenmesi amaçlanmıştır. Montessori ve nörobilimi doğrudan ilişkilendiren (Catherine, Javier ve Francisco, 2020; Fabri ve Fortuna, 2020; Tomele ve Lidaka, 2017) çalışmalar doğrultusunda anahtar kelimeler genişletilerek "Montessori", "Montessori ve Bilim", "Montessori ve Beyin", "Montessori ve Nörobilim", "Beyin ve Öğrenme", "Beyin Temelli Öğrenme", "Beyin ve Hassas Dönemler", "Beyin ve Hareket", "Beyin ve Dil", "Montessori and Science", "Montessori and Brain", "Brain and Learning", "Brain-based Learning", kelimeleri ile 1994-2020 yılları arasında yapılmış olan yayın ve araştırmalar derlenmiştir. İkinci aşamada ulaşılan çalışmaların nasıl seçildiğine ilişkin işlem basamaklarını gösteren tarama şeması Şekil 2'de gösterilmiştir.

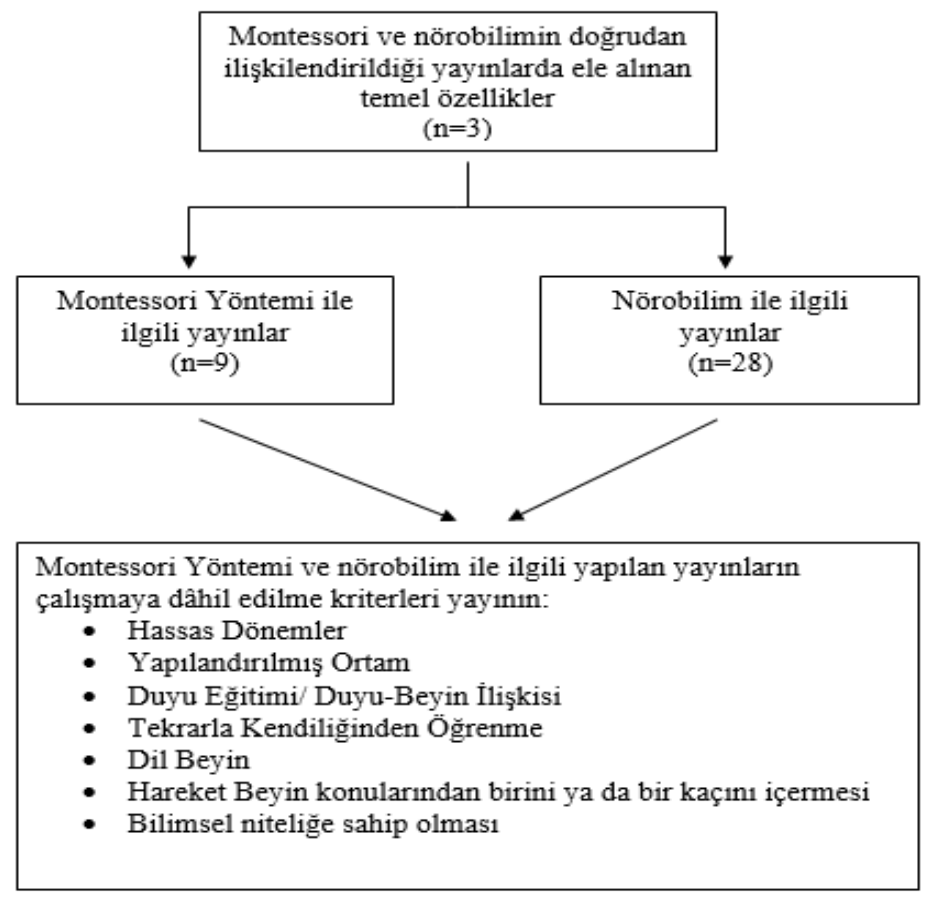

Şekil 2. İkinci Aşamada Yapılan Tarama Sürecini İçeren Akış Şeması 
Şekil 2'deki tarama sürecini içeren akış şemasında görüldüğü gibi birinci tarama çalışması sonucunda ulaşılan Montessori Yöntemi ve nörobilimin ilişkilendirildiği üç çalışmada iki alanın ilişkilendirildiği "Hassas Dönemler", "Yapılandırılmış Ortam”, “Duyu Eğitimi/ Duyu-Beyin İlişkisi”, “Tekrarla Kendiliğinden Öğrenme”, "Dil- Beyin” ve "Hareket- Beyin" temel özelliklerden yola çıkılarak Montessori Yöntemi ve nörobilim alanlarında ayrı ayrı yapılmış olan çalışmalar incelenmiştir. Yapılan tarama sonucunda her iki alana yönelik çok sayıda araştırmaya ulaşılmıştır. $\mathrm{Bu}$ nedenle yapılmış olan yayınların araştırmaya dâhil edilme kriterleri belirlenmiştir. Bu kriterlere göre sadece ilgili temel özelliklerin her iki alanda tartışılabileceği bilimsel yayınlar araştırmaya dâhil edilmiştir. Araştırma sonuçları bulgular bölümünde Tablo 2 ve Tablo 3’te verilmiş ve ilgili araştırmalar tartışma bölümünde incelenmiştir.

Orijinalliğini Kontrol Etme: $\mathrm{Bu}$ aşamada, tarama sonucu analize dâhil edilen çalışmaların özgün olup olmadığı kontrol edilmiştir. Çünkü araştırmaya dâhil edilen çalışmaların özgün olmaması araştırmacıların güvenirliğini sorgulatacak ve çalışmaya harcanan emek ve zaman boşa gitmiş olacaktır (Yıldırım ve Şimşek, 2016, s. 195). Bu doğrultuda incelenen çalışmalar temel alanlarına ve bilimsel araştırma yöntemlerine göre karşılaştırılarak özgünlüğü gözden geçirilmiştir.

Dokümanları Anlama: Dokümanların anlaşılması ve çözümlenmesi aşamasında, makaleler araştırmacılar tarafından detaylı bir şekilde okunmuş daha sonra araştırma amac1, yöntemi, bulguları bir tabloda özetlenmiştir.

Veriyi Analizi Etme: Bu aşamada, belirlenen çalışmalar içerik analizi yöntemi ile analiz edilmiştir. İçerik analizinde temel amaç, elde edilen verileri açıklayabilecek kavramlara ve ilişkilere ulaşmaktır. Bu amaçla yapılan işlem, birbirine benzeyen verileri belirli kavramlar ve temalar doğrultusunda bir araya getirmek ve okuyucunun anlayacağ1 şekilde yorumlamaktır. $\mathrm{Bu}$ doğrultuda veriler, verilerin kodlanması, temaların oluşturulması, kodların ve temaların değerlendirilmesi, bulguların tanımlanması ve yorumlanması olmak üzere dört aşamada analiz edilmektedir (Yıldırım ve Şimşek, 2016, s. 243). Bu doğrultusunda elde edilen kaynaklar öncelikle yayın türüne göre makaleler M, kitaplar ise K olarak kodlanmıştır. Daha sonra ulaşılan kaynaklarda Montessori Yöntemi ve nörobilimin ilişkilendirildiği temel konular incelenerek temalar 
oluşturulmuştur. Bu temalar "Hassas Dönemler", "Yapılandırılmış Ortam”, "Duyu Eğitimi/ Duyu-Beyin İlişkisi”, “Tekrarla Kendiliğinden Öğrenme”, "Dil- Beyin” ve "Hareket- Beyin" dir. Elde edilen kaynaklar araştırmacılar tarafından ayrı ayrı kodlanarak belirlenen temalara yer verme durumuna göre analiz edilmiştir. Son olarak araştırmacıların ayrı ayrı yaptığı kodlar ve analizler bir araya getirilerek karşılaştırılmış ve son şekli verilmiştir.

Veriyi Kullanma: Son aşamada, elde edilen veriler Montessori eğitimi ve nörobilim alanlarında ele alınmış ve karşılaştırılarak yorumlanmıştır.

\section{Etik Kurallara Uygunluk}

$\mathrm{Bu}$ araştırma, alanyazında yer alan çalışmaların derlenmesi yoluyla gerçekleştirildiği için etik kurul onayı gerektirmemektedir.

\section{BULGULAR}

$\mathrm{Bu}$ bölümde, öncelikle birinci aşamada doküman analizine tabi tutulan çalışmaların yazarları, yılı, kaynak türü ve ele aldıkları konu başlıklarına yer verilmiştir. Daha sonra ise birinci taramada elde edilen temel konu başlıklarına göre ikinci taramada incelenen çalışmalara yer verilmiştir. Makaleler M, kitaplar K, Bildiriler ise B şeklinde kodlanmış ve kaynak türü bölümünde belirtilmiştir.

\section{Birinci tarama çalışmasından elde edilen bulgular}

Montessori Yöntemi ile nörobilimsel çalışmaların incelendiği 2017-2020 yılları arasında yapılmış olan üç çalışmaya ulaşılmıştır (Tablo 1). 
Tablo 1. Montessori ile Nörobilimin Doğrudan İlişkilendirildiği Araştırmalar ve İlişkilendirilen Konu Başlıkları

\begin{tabular}{|c|c|c|c|c|c|c|c|}
\hline 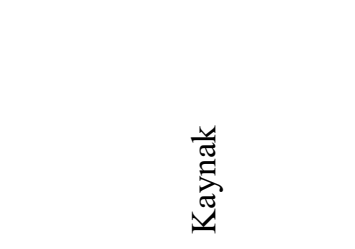 & 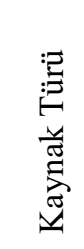 & 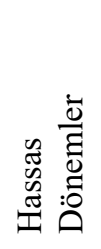 & 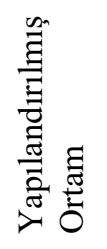 & 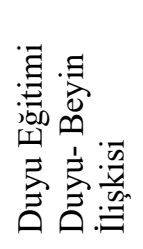 & 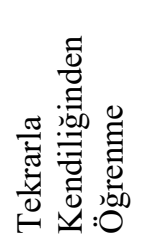 & 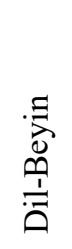 & 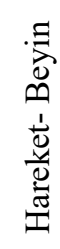 \\
\hline $\begin{array}{l}\text { Catherine, Javier ve } \\
\text { Francisco, } 2020 \\
\end{array}$ & M & $\mathrm{X}$ & $\mathrm{X}$ & $\mathrm{X}$ & $\mathrm{X}$ & & \\
\hline Fabri ve Fortuna, 2020 & $\mathrm{M}$ & $\mathrm{X}$ & $\mathrm{X}$ & $\mathrm{X}$ & & $\mathrm{X}$ & $\mathrm{X}$ \\
\hline Tomele ve Lidaka, 2017 & $\mathrm{~B}$ & & & & & $\mathrm{X}$ & \\
\hline
\end{tabular}

$\mathrm{Bu}$ çalışmalar, Montessori yöntemi ve nörobilimsel çalışmalarda ilişkilendirilen konu başlıklarına göre analiz edilmiştir. Analiz sonucunda, Montessori yönteminde yer alan "Hassas Dönemler", "Yapılandırılmış Ortam", "Duyu Eğitimi", "Tekrarla Kendiliğinden Öğrenme", "Dil-Beyin" ve "Hareket-Beyin" temel özelliklerinin nörobilimsel araştırmalar kapsamında incelendiği ve tartışıldığı görülmüştür.

\section{İkinci tarama çalışmasından elde edilen bulgular}

Montessori eğitiminin nörobilimsel araştırmalarda ele alınan özellikleri belirlendikten sonra bu özellikler doğrultusunda yeniden yapılan literatür taramasında 1994-2020 yılları arasında yayınlanmış olan 26'sı makale, 11'i kitap olmak üzere toplam 37 kaynak incelenmiştir (Tablo 2 ve Tablo 3). 
Tablo 2. Birinci Tarama ile Belirlenen Anahtar Kelimelerin Montessori Yöntemi Çalışmalarında Ele Alınma Durumu

\begin{tabular}{|c|c|c|c|c|c|c|}
\hline 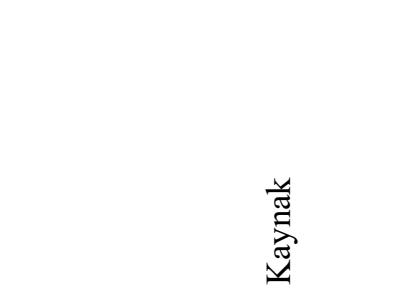 & 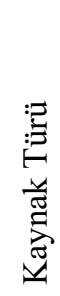 & 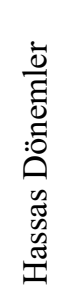 & 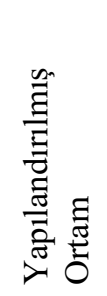 & 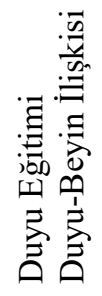 & 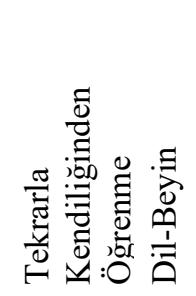 & 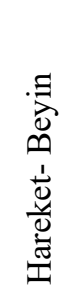 \\
\hline Lillard, (2020) & $\mathrm{M}$ & & $\mathrm{X}$ & & $\mathrm{X}$ & \\
\hline Çakıroğlu Wilbrandt, (2019) & $\mathrm{K}$ & $\mathrm{X}$ & $\mathrm{X}$ & $\mathrm{X}$ & $\mathrm{X}$ & $\mathrm{X}$ \\
\hline Montessori, (2016) & $\mathrm{K}$ & & & $\mathrm{X}$ & & \\
\hline Olson \& Hergenhahn, (2016) & $\mathrm{K}$ & & & & $\mathrm{X}$ & \\
\hline Montessori, (2015) & $\mathrm{K}$ & $\mathrm{X}$ & & & $\mathrm{X}$ & $\mathrm{X}$ \\
\hline Lillard, (2014) & $\mathrm{K}$ & $\mathrm{X}$ & $\mathrm{X}$ & $\mathrm{X}$ & $\mathrm{X}$ & \\
\hline Lillard, (2013) & $\mathrm{K}$ & $\mathrm{X}$ & $\mathrm{X}$ & $\mathrm{X}$ & $\mathrm{X}$ & $\mathrm{X}$ \\
\hline Pollard, (1996) & $\mathrm{K}$ & & $\mathrm{X}$ & $\mathrm{X}$ & $\mathrm{X}$ & \\
\hline Temel, (1994) & $\mathrm{M}$ & & $\mathrm{X}$ & & & \\
\hline
\end{tabular}

Montessori eğitimi alanında yapılmış çalışmalar arasında, "Hassas Dönemler" konusunun ele alındığg dört kitaba; "Yapılandırılmış Ortam” konusunun ele alındığı iki makale ve dört kitaba; “Duyu Eğitimi/ Duyu Beyin İlişkisi” konusunun ele alındığı beş kitaba; "Tekrarla Kendiliğinden Öğrenme” konusunun ele alındığı bir makale ve beş kitaba; "Dil-Beyin İlişkisi” konusunun el alındığı iki kitaba; "Hareket-Beyin İlişkisi”" konusunun ele alındığı üç kitaba ulaşılmış ve incelenmiştir. 
Tablo 3. Birinci Tarama ile Belirlenen Anahtar Kelimelerin Nörobilim ile Beyin ve Öğrenme Çalışmalarında Ele Alınma Durumu

\begin{tabular}{|c|c|c|c|c|c|c|}
\hline 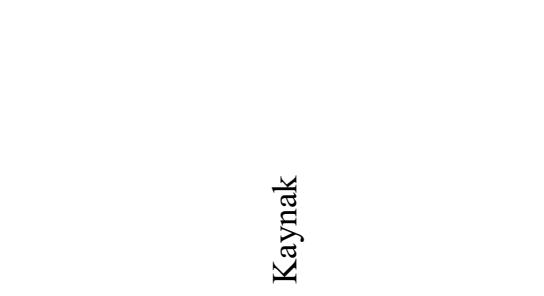 & 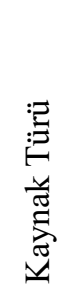 & 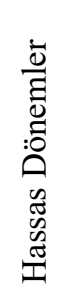 & 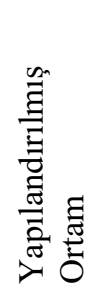 & 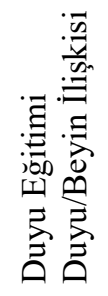 & 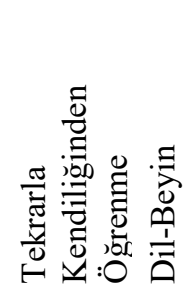 & 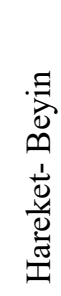 \\
\hline Arechavala-Lopez vd., (2020) & $\mathrm{M}$ & & $\mathrm{X}$ & & & \\
\hline $\begin{array}{l}\text { Gabard-Durnam ve McLaughlin, } \\
(2020)\end{array}$ & M & $\mathrm{X}$ & $\mathrm{X}$ & & & \\
\hline $\begin{array}{l}\text { Gopalakrishnan, Karpagam, Selvaraj, } \\
2020\end{array}$ & M & & & $\mathrm{X}$ & & \\
\hline Reh vd., (2020) & $\mathrm{M}$ & $\mathrm{X}$ & & & & \\
\hline $\begin{array}{l}\text { de Giorgio, Kuvacic, Milic \& Padulo, } \\
2018\end{array}$ & M & & & & & $\mathrm{X}$ \\
\hline Özdoğru, Kaya Yertutanol, (2018) & $\mathrm{M}$ & & & & & $\mathrm{X}$ \\
\hline Davis vd., (2017) & $\mathrm{M}$ & & & $\mathrm{X}$ & & \\
\hline $\begin{array}{l}\text { Demir, Usta, Yayla, Taşkın, Hastunç } \\
\text { ve Alav, (2016) }\end{array}$ & M & & & & & $\mathrm{X}$ \\
\hline $\begin{array}{l}\text { Friederici, Chomsky, Berwick, Moro } \\
\& \text { Bolhuis, (2017) }\end{array}$ & M & & & & $\mathrm{X}$ & \\
\hline $\begin{array}{l}\text { Barker, Semenov, Michaelson, } \\
\text { Provan, Snyder, Munakata (2014) }\end{array}$ & M & & & & $\mathrm{X}$ & \\
\hline Tottenham, $(2014)$ & $\mathrm{M}$ & & & & $\mathrm{X}$ & \\
\hline $\begin{array}{l}\text { Vries, Fields, Peters, Whylings \& } \\
\text { Paul, } 2014\end{array}$ & M & $\mathrm{X}$ & $\mathrm{X}$ & & & \\
\hline Ericson, Gildengers \& Butters, (2013) & $\mathrm{M}$ & & & & & $\mathrm{X}$ \\
\hline Ergenç, (2008) & $\mathrm{K}$ & & & & $\mathrm{X}$ & \\
\hline Kuhl \& Rivera-Gaxiola, (2008) & $\mathrm{M}$ & & & & $\mathrm{X}$ & \\
\hline Lores-Arnaiz vd., (2007) & $\mathrm{M}$ & & $\mathrm{X}$ & & & \\
\hline $\begin{array}{l}\text { National Scientific Council on the } \\
\text { Developing Child, (2007) }\end{array}$ & M & $\mathrm{X}$ & & & & \\
\hline Friederici, (2006) & $\mathrm{M}$ & & & & $\mathrm{X}$ & \\
\hline Jensen, (2006) & $\mathrm{K}$ & & $\mathrm{X}$ & & & $\mathrm{X}$ \\
\hline Nithianantharajah ve Hannan, (2006) & $\mathrm{M}$ & & $\mathrm{X}$ & & & \\
\hline $\begin{array}{l}\text { Casey, Tottenham, Liston \& Durston, } \\
2005\end{array}$ & M & & & $\mathrm{X}$ & & \\
\hline Hensch, 2005 & $\mathrm{M}$ & $\mathrm{X}$ & & & & \\
\hline
\end{tabular}




\begin{tabular}{lllll}
\hline $\begin{array}{l}\text { Dronkers, Wilkins, Van Valin, } \\
\text { Redfern \& Jaeger, (2004) }\end{array}$ & M & & X \\
\hline $\begin{array}{l}\text { Grossman, Churchill, McKinney, } \\
\text { Kodish, Otte, Greenough, (2003) }\end{array}$ & M & X & & \\
\hline Greenough, (2002) & K & & X \\
\hline Greenough, Black \& Wallace, (2002) & K & X & & X \\
\hline Diamond (2001) & M & & X & \\
\hline $\begin{array}{l}\text { Viru, Loko, Harro, Volver, Laaneots, } \\
\text { \& Viru (1999) }\end{array}$ & M & X & & \\
\hline
\end{tabular}

Nörobilim, beyin ve öğrenme alanlarında yapılmış çalışmalar arasında, "Hassas Dönemler" konusunun ele alındığı yedi makale ve bir kitaba; "Yapılandırılmış Ortam" konusunun ele alındığı altı makale ve bir kitaba; "Duyu Eğitimi/ Duyu Beyin İlişkisi" konusunun ele alındığı üç makaleye; “Tekrarla Kendiliğinden Öğrenme” konusunun ele alındığı iki makale ve iki kitaba; "Dil-Beyin İlişkisi” konusunun el alındı̆̆ı dört makale ve bir kitaba; "Hareket-Beyin İlişkisi” konusunun ele alındığı dört makale ve bir kitaba ulaşılmış ve incelenmiştir.

\section{TARTIŞMA}

Bu bölümde, araştırmanın "Montessori yönteminin hangi özellikleri nörobilim alanında yapılan beyin ve ögrrenme ile ilgili keşiflerle desteklenmektedir?" sorusuna cevap aramak amaciyla doküman analizi sonucu belirlenen Montessori yöntemindeki Hassas Dönemler, Yapılandırılmış Ortam, Duyu Eğitimi, Tekrarla Kendiliğinden Öğrenme, Dil ve Beyin Illişkisi, Hareket ve Beyin İlişkisi temel konuları birinci ve ikinci aşamada elde edilen Montessori yöntemi ve nörobilim alanında yapılan ilgili çalışmalar kapsamında tartışılmıştır.

\section{"Hassas Dönemler"e Nörobilimsel Bakış Açısı}

Montessori'nin Jean Marc Itard (1774-1838) ve Edourad Séguin'in (1812-1880) çalışmalarının etkisi ile ortaya koyduğu "hassas dönemler"; hareket, düzen, dil, duyu gelişimi gibi belirli kazanımların edinilmesine izin veren, çocukluğun belli dönemine özgü firsat pencereleri olarak değerlendirilebilir (Catherine, Javier ve Francisco, 2020). 
Montessori, bu belirli dönemlerde çocukların kendi zihin kaslarını oluşturduğunu ve bunu sağlamak için de çevrelerinde bulduklarını kullandıklarını ifade ederek çocukların zihin yapısını "Emici Zihin" olarak adlandırmıştır (Montessori, 2015, s. 35). Montessori’ye göre çocuk, belirli alanlarda alıcı olduğu ve bir dizi özel yetenek ve becerileri edindiği hassas dönemler boyunca, fiziksel ve biyolojik gelişimin birlikte devam ettiği ruhsal bir embriyodur (Catherine, Javier ve Francisco, 2020). Çocuk hassas dönemlerde, gelişiminin yalnızca belirli bir alanı üzerinde çalışıyor gibi görünür (Lillard, 2014, s. 52). Örneğin çocuk, dile, hareket etmeye, düzen ve sosyalleşemeye karşı duyarlılık gösteriyorsa buna göre eğitilmesi gerekmektedir (Çakıroğlu Wilbrandt, 2019, s. 52). Çünkü bu evreler geçicidir, yalnızca çocuklukta ortaya çıkar ve altı yaşından sonra varlıklarını aynı şekilde ve yoğunlukta gösterdiklerine dair bir kanıt bulunmamaktadır (Lillard, 2013, s. 69). "Hassas dönemler”; duyu eğitimi, hazırlanmış çevre ve tekrar yoluyla kendiliğinden öğrenme gibi diğer özelliklerin açıklanmasında da aracı role sahiptir (Catherine, Javier ve Francisco, 2020). Hassas dönemlerde çocuğa duyusal deneyimler ve ortam sağlandığında bu firsat pencerelerini etkili kullanabilir.

Montessori'nin hassas dönemler ile ilgili deneyimleri 1960'lara gelindiğinde öncelikle hayvanlar üzerinde yapılan nörobilimsel çalışmalar ile destek bulmuş, çocukluk dönemindeki hayvanların beyinlerinin yüksek düzeyde şekillenebilir ve çevre tarafından etkilenebilir olduğuna dikkat çekilmiştir (Fabri ve Fortuna, 2020). Günümüzde ise daha yüksek bilişsel yetenekler, alıcı dil alanları/konuşma üretimi ve işitme/görme gibi gelişimsel çıktılar için sinaps oluşumunun farklı aylarda gerçekleştiği ve bu zamanların kritik dönemler olduğu nörobilimsel araştırmalar ile vurgulanmaktadır (National Scientific Council on the Developing Child, 2007). Beyindeki hassas dönemler ile ilgili araştırmalar yapan Hensch (2005), beyindeki nöronal devrelerin doğum sonrası erken yıllardaki bazı özel dönemler boyunca elde edilen deneyimler yoluyla şekillendiğini belirtmektedir. Yapılan diğer nörobilimsel araştırmalar incelendiğinde de beyin ve davranış gelişimi dahil çok çeşitli süreçlerin yer aldığı belirli dönemlerde organizmanın çevresel faktörlerden etkilendiği (Vries, Fields, Peters, Whylings \& Paul, 2014, s. 80) ve bu dönemlerin "kritik dönemler" olarak ifade edilebileceği beyin plastisitesinin yaşam boyunca dinamik olarak düzenlendiği özellikle de yaşamın ilk yıllarında zirve 
yaptığı (Reh vd., 2020) ve beyinde çok fazla sinaps oluşumunun gerçekleştiği (Greenough, Black \& Wallace, 2002, s. 186), beynin çevresel deneyimlere açık bir plastisiteye sahip olduğu, bu dönemlerin öğrenme ve plastisiteye yardım eden çevresel deneyimleri nörobiyolojik olarak kodladığı (Gabard-Durnam ve McLaughlin, 2020) belirtilmektedir. Bununla birlikte beyin gelişiminin temel süreçlerinin çoğunun genetik olmayan etkilere özellikle de deneyimlere karşı duyarlı olduğu ve bu deneyimlerin genetik özellikler üzerinde etkili olduğu, bu dönemlerde uygun deneyimler yaşanmaması durumunda bazı psikopatolojik sorunlar oluşabileceği (Grossman vd., 2003) çocukların ilerleyen yıllardaki performans kapasitelerinin gelişimini etkileyeceği (Viru vd., 1999) belirtilmektedir.

Nörobilimde de "kritik dönemler" belirli deneyimlerin belirli gelişim aşamalarında belirli beyin devrelerini etkilemesi olarak karşılık bulmaktadır. Diğer bir deyişle bir çocuğun erken ve gelişimin doğru aşamalarında uygun deneyimlere ulaşılabilirliği beyin mimarisinin güçlü veya zayıf yönlerini belirlemede kritiktir. Bu durum çocuğun düşünme ve duyguları düzenleyebilmeyi ne kadar iyi yapabileceğini belirler. İlk yıllarda, yeterli besinler, etkili bir bakım verenle ve sosyal etkileşimlerle dolu büyümeyi teşvik eden bir ortam, gelişmekte olan beynin mimarisini sağlıklı bir ortamda en iyi şekilde çalışması için hazırlar. Tersi durumlar ise beyin gelişiminde aksaklıklara neden olabilir. Çocuğun çevresi ile etkileşimini ifade eden deneyimler doğumdan önce başlar. Fetüsün çevresini algılaması ve tepki vermesi, doğumdan sonra ise bebeğin çevre ile etkileşimleri, sinir devrelerinin ve beyin kapasitesinin şekillenmesinde son derece önemli rol oynamaktadır. Çünkü kritik dönemler bittikten sonra sinir devrelerini değiştirmek çok daha zordur. Çevrenin özelliğine göre kritik dönemler çocuk için firsatlar veya savunmasızlıklar yaratabilir (National Scientific Council on the Developing Child, 2007). Nörobilim alanında yapılan bu çalışmaların Montessori'nin "Hassas Dönemler" açıklamaları ile paralellik gösterdiği, özellikle erken çocuklukta deneyim zenginliği sağlanarak çocukların beyin performanslarının arttırılabileceği söylenebilir. 


\section{"Yapılandırılmış Ortam"a Nörobilimsel Bakış Açısı}

Montessori ilk yaptığı gözlemlerde çocukların kalabalık sınıflarda, sıra sıra oturduklarını ve öğretmenin söylediği her şeyi tekrar ettiklerini gözlemlemiş, okullardaki havayı hapishane havasına benzetmiştir. Öğretmenler çok nadir gülümsüyorlar ve öğrencilerle kaba şekilde konuşuyorlar, onları hiç sevmiyormuş gibi davranıyorlar ve her firsatta cezalandırıyorlardı. Binalar ise oldukça kasvetli ve sıkıcıydı (Pollard, 1996, s. 25). Bu gözlemler onun çocuğun gelişiminde ve öğrenmesinde çevrenin ve motivasyonun kritik bir rolü olduğunu fark etmesini sağlamıştır (Fabri ve Fortuna, 2020). Çocuklar ortamdaki düzene karşı duyarlıdırlar. Düzenli bir çevrede kendisini güvende hissetmeleri, davranışlarını çevreye uydurmaları ve hâkimiyet kurmaları açısından gereklidir. Bu doğrultuda Montessori'de çocuklara gelişimlerine uygun materyaller ile rahat hareket edebilecekleri bir ortam sunulur (Çakıroğlu Wilbrandt, 2019, s. 52-58). Ayrıca materyaller çocuğun gerçekle yüz yüze gelmesine yardımcı olmak için gerçek yaşamda kullanılan araçlardan oluşmakta ve günlük hayattaki gibi her materyalden bir tane bulunmaktadır. Böylece çocuk bilgi, beceri öğrenmenin yanı sıra bir materyalle vakit geçirmek için sırasını beklemekte ve günlük yaşamdaki gibi başkalarının işine saygı duymayı öğrenmektedir (Temel, 1994).

Montessori çocukların gelişimlerine uygun olarak geliştirdiği ve farklı duyulara hitap eden, çocuklar tarafından hata kontrolünün sağlanabildiği (Catherine, Javier \& Francisco, 2020) materyaller ile çocuklar için zenginleştirilmiş bir ortam hazırlamış ve bu ortamın çocukların zihinsel gelişimlerine, öğrenmelerine, bilgi, beceri ve davranış edinmelerine oldukça fazla katkı sağladığını keşfetmiştir. Yapılandırılmış çevre yöntemin öncelikli ögesi olarak düşünülmekte ve çocuğu besleyen bir yer olarak nitelendirilmektedir (Lillard, 2013, s. 93). Çevre yapılandırılmış veya hazırlanmış olması çocukları sınırlandırmaz, yapılandırma zenginliği içerir, çocuk zengin çevrede öğrenme özgürlüğünü kullanır. Yapılandırılmış ortamda bir dizi malzeme, bu malzemeleri kullanmanın yolları ve yapıda kabul edilebilir davranışların kodları vardır. Ancak bu yapı içerisinde çocuklar günlük olarak hangi etkinliklerde, kiminle ve ne kadar süre oynayacaklarını kendileri seçmektedirler (Lillard, 2020). Çocuk çevre ile etkileşimi ile kendi öğrenmesini sürdürürken, öğretmen de çevreyi bilimsel olarak 
planlayıp yöntemsel olarak biçimlendirir, çocukların içsel motivasyon geliştirmelerine model olur (Lillard, 2014, s. 110).

Nörobilimsel açıdan çevrenin rolüne bakıldığında ise beyindeki donanımın \%30-60 oranında katılım yoluyla, \%40-70 oranında ise çevrenin etkisiyle belirlendiğine ilişkin fikir birliği vardır. Çevre en az bireyin kişisel deneyimleri kadar beyindeki ağın gelişimine etki etmektedir. Yeni öğrenme deneyimleri ve çaba gerektiren girişimci etkinlikler beynin gelişimi için kritik bir öneme sahiptir ve beyin için besin gibidir. Beyin çevresindeki dokunuşları, tatları, kokuları, sesleri görüntüleri girdi olarak almakta ve bu girdilerden sayısız sinirsel bağlantılar oluşturmaktadır. Böylece, çevresindeki dünyayı anlamlandırmaya başladığında içeride de sinir ağlarından oluşan zengin ve güçlü bir yapı kurmaktadır (Jensen, 2006, s. 30-32).

Yapılan bazı araştırmaların sonucunda, orta beyinde yer alan ve dikkat süreciyle ilgili olan superiror collicusun zenginleştirilmiş ortamlarda \%5-6 oranında daha fazla büyüdüğü, bu ortamlarda gerçekleşen öğrenmenin beyin ağırlığındaki artışla, beyin dokusundaki dendritik dallanmanın artmasıyla, nörotransmitter düzeylerinin yükselmesiyle ve beynin başka fiziksel değişimleriyle ilgili olduğu ve beyin üzerindeki bu etkilerin davranışları değiştirdiği belirtilmiştir (Diamond, 2001; Jensen, 2006, s. 31).

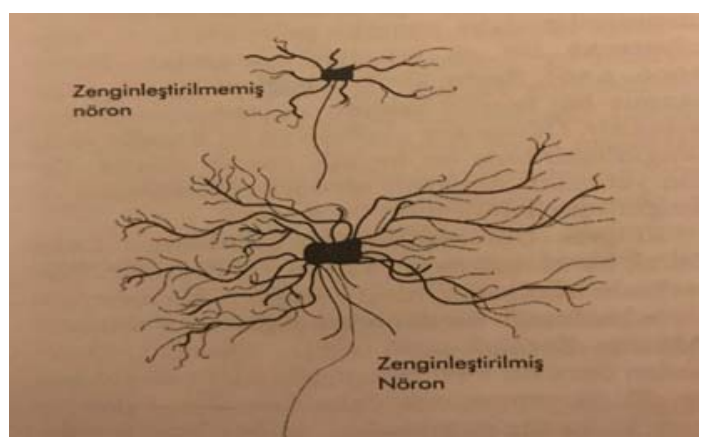

Şekil 3. Zenginleştirilmiş ve zenginleştirilmemiş nöronlar (Jensen, 2006, s. 31) 
Şekil 3'te de görüldüğü gibi zenginleştirilmiş, önceden hazırlanmış ortamların sinapsları beslediği ve çocukların beyin gelişimlerinde oldukça etkili olduğu söylenebilir. Nörobilimde yapılan bazı araştırmalar neticesinde de zenginleştirilmiş ortamın sinapsları beslediği ve beyin gelişimine önemli katkılar sağladığı tespit edilmiştir (Arechavala-Lopez vd., 2020; Lores-Arnaiz vd., 2007; Nithianantharajah ve Hannan, 2006). Uzun yıllar zenginleştirilmiş çevrenin beyin üzerindeki etkisine yönelik araştırmalar yapmış olan Marian C. Diamond (2001), 1960’lardan önce insan beyninin genetik kontrole tabi olduğunun ve dolayısıyla değişmediğinin düşünüldüğünü ifade etmiş ve hayvanlar üzerinde yapılan deneyler neticesinde zenginleştirilmiş çevrenin beyin üzerindeki etkilerinin görüldüğünü, üst düzey bilişsel işlemeyle ilişkili olan serebral korteksin çevresel etkilere karşı beynin diğer bölümlerinden daha alıcı olduğunu ve zenginleştirilmiş çevrenin insan beyni üzerindeki etkilerinin davranışları değiştirdiğini belirtmiştir. Kritik dönemlerde de vurgulandığı üzere çevre deneyim zenginliği sunma, öğrenmeyi güçlendirme ve sinapsisleri artırma bakımından çocukların beyin gelişimini etkilemektedir (Gabard-Durnam ve McLaughlin, 2020; Vries, Fields, Peters, Whylings \& Paul, 2014). Bu bağlamda, erken yıllarda çocukların gelişim ve öğrenmelerinde yapılandırılmış ortamda özgür deneyimler sağlanmasının önemli olduğu, Montessori yönteminin de ortamın çocuğa donanım bakımından zengin, düzenli ve estetik bir şekilde sunulması, farklı gelişim alanlarına özel duyusal materyallerin olması, materyallerin öğrenmeyi aşama aşama ilerletmesi gibi açılardan beyin gelişimi için temel olan özellikleri desteklediği söylenebilir.

\section{"Duyu Eğitimi"ne Nörobilimsel Bakış Açısı}

Zihnin temel işlevlerinin duyuları geliştirici materyallerle uyarıldığını ve deneyim kazandırılarak öğretildiğini belirten Montessori tüm duyu organlarına yönelik materyaller geliştirmiştir (Çakıroğlu Wilbrandt, 2019, s. 119). Montessori'nin eğitilemez olarak nitelendirilen çocuklara dokunma, duyma, koklama ve görme gibi duyuları uyaran materyaller sağlayarak yaptığı ilk deneyimler bu çocukların diğer çocukların ulaştıkları standartlara ulaşabilmelerini ve aynı testlerde başarılı olabilmelerini sağlamıştır (Pollard, 1996, s. 7-10). Bu sonuçlar eğitimde duyuların gelişimine ve etkin 
kullanılmasına dikkat çekmiş, eğitim materyallerinin geliştirilmesine de rehberlik sağlamıştır.

Montessori eğitimde biyolojik ve toplumsal olmak üzere iki yönlü amaç benimsediğini ifade etmektedir. Biyolojik amaç, bireyin doğal gelişimine destek olmak, toplumsal amaç ise bireyin çevresine uyumunu desteklemektedir. Montessori’ye göre duyuların eğitimi her iki amaç doğrultusunda da oldukça önemlidir. Duyuların gelişimi 3-6 yaş arasında daha üst yeteneklerin gelişiminden önce gerçekleşir (Montessori, 2016, s. 169170). Çocuk tat alma ve dokunma yoluyla çevresindeki nesnelerin niteliklerini özümseyerek buna göre davranmaya başlar. Konuşma için gerekli nörolojik yapılar da bu duyusal ve motor etkinlikler yoluyla gerçekleşir. Bundan dolayı insanın konuşmak için kullandığı dil ve çalışmak için kullandığı eller bedenin diğer tüm kısımlarına kıyasla insan zekâsı ile yüksek oranda ilişkilidir (Lillard, 2013, s. 67).

Duyu eğitimi ile ilgili olarak Montessori (1948) "Çocuğun Keşfi" kitabında şu ifadelere yer vermiştir:

"Bilindiği gibi üç ila altı yaş arasındaki yaşam döneminin en belirgin özelliği, hızlı fiziksel büyüme ve psişik yeteneklerin gelişmesidir. Bu yıllarda çocuğun duyuları gelişir ve bu nedenle de dikkati çevresine yönelmiştir. Muhakemeden çok uyarıcılar ilgisini çeker. Bu nedenle de bu dönemde duyularının rasyonel bir şekilde gelişmesini sağlayacak uyarıcılara sistemli bir şekilde maruz kalması gerekir. Bu da zihinsel gücünün temellerini atar” (Montessori, 2016, s. 170).

Yukarıdaki ifadelerinde de görüldüğü gibi erken çocukluk döneminde duyuların eğitimi oldukça önemlidir ve duyuların uygun materyallerle geliştirilmesi zihin performansını artıracaktır.

Catherine, Javier \& Francisco (2020), Montessori'nin duyu eğitimi amacının çocukları duyusal deneyim bombardımanına tutmak olmadığını, çocukları duyusal keskinliği ve ayrımcılığı sağlayan materyallerle desteklemeyi içerdiğini ve sonunda çocukların soyut düşünmeye ulaşacaklarını, daha fazla kaynağa sahip olacaklarını belirtmişlerdir (s. 8). Montessori, "El beynin organıdır" sözüyle de küçük nesne manipülasyonunun nöropsikolojik açıdan hayati rolü olduğu fikrini savunarak duyusal- motor işlevlerin ilişkisini açıklamıştır. Çocuğum zekâsını, beyinle birlikte işleyen elin oluşturduğunu belirtmiştir (Fabri \& Fortuna, 2020). Montessori’nin eğitim ilkelerinden birisi beyne 
hiçbir zaman ele verilenden daha fazlasını vermemektir. El ve beynin özümseyen beyin ve duyarlı dönemlerle güçlenen, birlikte işleyen zihinsel süreci çocuk altı yaşına geldiğinde kişilik bütünleşmesi ile bir araya gelir (Lillard, 2014, s. 54).

Montessori’nin çalışmaları ile nörobilimsel çalışmaları karşılaştıran Fabri \& Fortuna (2020), beyin haritalaması çalışmalarının el üzerinde, elin kendi boyutunu aşacak şekilde hareketlerini ve duyusal bilgiyi işlemeyi içeren çok sayıda nöronun motor ve duyusal kortikollerde yer aldığını gösterdiğini belirtmişlerdir (s. 398).

Duyular ve sinir sisteminin ilişkisine nörobilimsel bakış açısıyla bakıldığında Montessori'nin görüşlerini destekler çalışmalar yapıldığı görülmektedir. Duyular ve sinir siteminin ilişkili olduğu, duyusal ve motor süreçler gibi temel işlevlerle ilgili beyin bölgelerinin daha önce olgunlaştığı ardından davranışların yukarıdan aşağıya kontrolünü sağlayan ilgili bölgelerin geliştiği (Casey, Tottenham, Liston \& Durston, 2005) ve beyindeki hasarların iyileşmesinde duyusal ortamların son derece etkili olduğu görülmüştür (Gopalakrishnan, Karpagam, Selvaraj, 2020). Bununla birlikte yaşamın ilk yıllarında annelerin duyuşsal sinyallerinin çocukların bilişsel gelişimleri üzerinde etkili olduğu (Davis vd., 2017) görülmüştür. Uygun duyusal uyaranlar beyin gelişimini dolayısıyla bilişsel gelişimi olumlu yönde etkilemektedir. Beyinde meydana gelen hasarlar ise duyusal fonksiyonları etkilemektedir. Montessori'nin ifade ettiği ve nörobilimsel bulguların da gösterdiği gibi duyular ve zihin birbiriyle ilişkilidir ve duyu eğitimi sağlıklı bir zihin gelişimi için oldukça kritik bir rol oynamaktadır.

\section{"Tekrarla Kendiliğinden Öğrenme"ye Nörobilimsel Bakış Açısı}

Montessori, çocukların kendileri için öğrenmeyi sevdiklerini gözlemlemiş, eğitim uygulamalarında ödülleri kaldırmıştır. Hatta bir gözleminde çocuğun zorlayıcı bir egzersizle derin bir şekilde meşgul olduğunu ve hatta o anda çevresindekileri bile fark etmediğini ve alıştırmayı (10 dereceli silindiri, 10 eşleşen deliğe yerleştirme), kırk kadar kez tekrarladığını ve sonunda çocuğun ferahlamış olduğunu fark etmiştir. Bu durum çocukların hem tekrar ederek öğrendiklerini hem de konsantrasyonun gelişimsel olarak önemli olduğunu ortaya koymuştur (Lillard, 2020). Montessori’ye göre çocuklara doğru malzeme ve deneyim firsatı verilirse çocuklar zaten öğrenmek istemektedirler (Pollard, 
1996, s. 25). Çocuk Montessori ortamında günlük yaşam, duyu, matematik, dil ve kozmik gibi alanlarda birçok materyaller ile çalışır. Tüm bu alanlar ve aktiviteler, doğal (spontan) tekrarlar yoluyla öğrenmenin somutlaştırılmasını sağlar (Catherine, Javier ve Francisco, 2020). Çocukta öğrenmenin güçlü bir şekilde gerçekleşmesini sağlayan nokta, öğretenin materyalin amacını anlatmasından sonra çocuğun materyali istediği zaman ve istediği sayıda kullanmasıdır (Lillard, 2014, s. 64). Çocuğun kendi gelişimini gerçekleştirmesine odaklanılır, çocuklar özel hazırlanmış materyaller ile çalışarak kendi kendilerine öğrenebilir, hatalarının farkına varabilirler (Lillard, 2013, s. 11). Tekrarlar çocukların hatalarını görmelerini ve öğrendiklerini içselleştirmelerini sağlar. Çocuk kendi kendine defalarca yaptığı tekrarlar yoluyla hareketle ilgili eşgüdüm de geliştirir (Çakıroğlu Wilbrandt, 2019, s. 58). Davranış̧̧ı yaklaşımlarda genel olarak anlamlı olmayan mekanik tekrarlar vardır. Ancak Montessori, çocuklar tarafından öğrenilecek olan görevler tasarlamak yerine çocuklar tarafından doğal olarak ortaya çıkan tekrar yoluyla, kendiliğinden öğrenmeyi "tetiklemek" için bir ortam hazırlamayı önermiştir. O, öğrenmenin eğitim yoluyla değil doğal tekrarlar yoluyla gerçekleştiğini anlamıştır. Psikolojik çalışmalarda, son dönemlerde belirtilen "Goldilocks Etkisi”ne göre çocuklar bazı şeyleri hassas dönemlerinde daha kolay öğrenmektedirler. Aşırı derece zor veya kolay etkinliklerden ziyade zorluk derecesi orta düzeyde olan etkinliklere dikkatli bir şekilde odaklanmaktadırlar. Böylece çocukların, hassas dönemlerine uygun olarak önceden hazırlanmış olan çevre, onların doğal aktivitelerinde yeterince zorlayıcı olan etkinlikleri kendilerinin seçmelerine izin verir. $\mathrm{Bu}$ durum da çocukların kendi gelişimlerine ve tekrarla öğrenmelerine katkıda bulunmaktadır (Catherine, Javier ve Francisco, 2020).

Tekrar yoluyla öğrenmeye nörobilimsel açıdan bakıldığında, çocukluk döneminde beyinin sinirsel olarak olgunlaşmamış olmasının önemli olduğu ve uzun süreli nöroplastisiteyi sağladığı ve bu durumun çevreden öğrenmeyi arttırdığı belirtilmektedir (Tottenham, 2014). Kişinin kendi çevresine ve diline özgü deneyime, tekrara bağlı öğrenmelerinde depolanacak olan bilgiye yanıt sağlamak için beyinde aktif bir şekilde yeni sinaptik bağlantılar kurulduğu (Greenough, Black \& Wallace, 2002, s. 187), beynin bağlantı şemasını değiştiren sinaptik ve dentritik değişikliklerin özellikle deneyim 
sonucu oluşan öğrenme ile ilgili olduğu görülmüştür (Greenough, 2002, s. 213). Devinimsel öğrenmelerin tekrar edilmesi (egzersiz) moleküler katmandaki kan damarlarının daha yoğun olmasını sağlamaktadır. Deneyimler hem dentritlerin uzunluğunu hem de dentritlerin üzerinde bulunan alıcıların sayısını değiştirmektedir. Bir nöronun sinapslarının \%95 kadarının dentritler üzerinde olduğu düşünüldüğünde dentrit uzunluğu ya da alıcı sayısındaki artışın yeni sinaptik bağlantılar kurulmasında, davranışsal ya da bilişsel değişmelere yansımasında etkili olabileceği söylenebilir (Olson \& Hergenhahn, 2016, s. 364). Çocukların yürütücü işlevlerine yönelik yapılan bir araştırmada çocukların yarı yapılandırılmış etkinliklerde yapılandırılmış etkinliklere oranla daha fazla zaman geçirdikleri, kendi kendilerine faaliyette bulundukları ve yürütücü işlevleri daha fazla kullandıkları görülmüştür (Barker vd., 2014)

$\mathrm{Bu}$ sonuçların, Montessori'nin, zenginleştirilmiş ve düzenlenmiş çevrede çocukların kendi kendilerine tekrar yoluyla öğrenmelerinin zihinsel gelişim ve kalıcı öğrenmede önemli olduğunu keşfetmesini destekler nitelikte olduğu söylenebilir.

\section{"Dil Gelişimi ve Beyin İlişkisi" ne Nörobilimsel Bakış Açısı.}

Bilinçaltında dil öğreniminin emici zihin sayesinde gerçekleştiğini söyleyen Montessori (Çakıroğlu Wilbrandt, 2019, s. 229), dilin insan düşüncesi ile birlikte geliştiğini ve bir nevi üst zekânın ifadesi olduğunu belirtmektedir. Çocukların dili emdiklerini belirtmiş ve bununla ilgili olarak "Konuşan insanlarla birlikte yaşayan çocukların kendileri de doğal olarak konuşmaya başlarlar” ifadelerini kullanmıştır. Montessori beyinde bulunan duyusal merkez ve motor merkezin biyolojik ve fiziksel olarak ayrı ayrı geliştiğini ifade etmiştir. İşitme organlarının çocukta dilin bilinçdışı gelişiminindeki etkisini, motor sistemin ise söylenen sözcüklerin tekrarı için gerekli son işlemlerle ilgili olduğunu ve ikinci bölümün daha yavaş ve diğerinden sonra geliştiğini belirtmiştir (Montessori, 2015, s. 124-132). Bu düşüncelerini söyle gerekçelendirmektedir:

"İnsana önceden kurulmuş bir dil verilmediyse doğal olarak çocuğun içinde bulunduğu halkın kullandığı sesleri yineleyebilmesi için önce bunları işitmesi gerekir. Öyleyse, sözcükleri yeniden üretmek için gereken hareketlerin zihne kaydedilmiş seslerden oluşan bir alt tabakaya dayanması lazımdır, çünkü çocuğun yapacağı hareketler önceden işittiği ve zihninde tutulmuş seslere dayanacaktır" (Montessori, 2015, s.132) . 
Dil gelişimi ile ilgili yer verilen ifadelerinde de görüldüğü gibi Montessori, gözlemleri neticesinde, insanlarda özellikle dil edinimini sağlayan nöral yapılar olduğunu savunmuştur. Nörobilim alanında yapılan teorik ve ampirik araştırma sonuçları Montessori’nin dil ve beyin ilişkisine yönelik teorik bilgisinin ve deneysel gözlemlerinin günümüzde Nörobilim'in sonuçları ile örtüştüğünü göstermektedir (Tomele ve Lidaka, 2017). Montessori’nin bu görüşüne kanıt olarak, dil yeteneklerinin nöral beyin yapılarında geliştiğini öne süren teoriyi geliştiren Noam Chomsky ve diğerlerinin çalışmaları gösterilebilir. Bu becerilerin beyinde tanımlanabilir bağlantıları vardır. Bu durum dilin yaklaşık 100.000 yıllık kökeninden beri değişmemiştir (Fabri ve Fortuna, 2020).

Nörolojik alanda yapılan araştırmalarda, dilin insan bilişinin temel taşlarından birisi olduğu (Friederici, Chomsky, Berwick, Moro \& Bolhuis, 2017), çocukların beyninde yetişkinlerinkine benzer şekilde, doğumdan itibaren lateralizasyon (yanallaşma) ile birlikte ilk aylarda fonolojik süreçlerin, 12. ayda semantik süreçlerin ve otuz ay civarında ise sözdizimsel süreçlerin yer aldığı dil fonksiyonlarının kurulu olduğu, dil ediniminin fazla çaba gerektirmeden ve beyin olgunlaştıkça gerçekleştiği (Friederici, 2006) ve sosyal etkileşimlerin dil ediniminde etkili olduğu (Kuhl \& Rivera-Gaxiola, 2008) belirtilmektedir. Beynin sol yarıküresinde yer alan üç kortikal alanının ve bu alanların birbirleri ile bağlantılarının dilin gelişimi açısından önemli rol oynadığı görülmüştür. Bu alanlar: Broca alanı, Wernicke alanı ve Angüler Girüs'tür. Dil bu alanlarla sınırlı olmamakla birlikte bu alanların ve birbirileri ile olan bağlantıların önemi oldukça fazladır. Frontal lobda yer alan Broca alanının görevi, diğer alanlarda üretilen seslerin konuşulan dile dönüştürülmesine yardımcı olmaktadır. Superior temporal girüsün arka yarısında ve üst yüzeyinde bulunan Wernicke alanının görevi, duyulanların söylenen biçimine dönüştürülmesinde kodlama ve duyulanların çözümlenmesine yardımcı olmaktır. Parietal lobda yer alan angüler girüs ise işitilenlerin yazılması, dokunulan nesnelerin adının yazılması ve okuma işlevleriyle ilgilidir (Ergenç, 2008). Dronkers ve arkadaşları (2004), dil ile ilgili beyinde sadece Wernicke ve Broca alanlarının olmayacağını ve başka alanların da dil gelişiminde etkili olabileceği hipotezine dayanarak sağ hemisferinde hasar olan hastalarla sol hemisferinde hasar olan 
hastaların dil gelişimlerini kapsamlı olarak incelemişlerdir. Araştırmada, sol hemisferde yer alan beş bölgedeki lezyonların (hasarların) dil gelişimini etkilediği görülmüştür. Araştırma sonucunda farklı beyin bölgelerinin dil gelişimi ve fonksiyonları ile ilgili olduğu görülmüştür.

Montessori’nin ve nörobilim araştırmalarının da ortaya koyduğu gibi beyinde dil ile ilgili birtakım mekanizmalar ve özel alanlar yer almaktadır (Tomele ve Lidaka, 2017). Dil gelişimi beyin gelişimi ile doğrudan ilişkilidir. Çocuklar dil gelişimini çevrelerini gözlemleyerek doğal olarak kazanabilirler. Dil gelişimini olumlu yönde desteklemede önemli olan nokta ise hazırlanmış ve uyarıcı materyallerin yer aldığı nitelikli bir çevrenin olmasıdır.

\section{"Hareket ve Beyin İlişkisi" ne Nörobilimsel Bakış Açısı}

Montessori'nin keşiflerinden en dikkat çekici olanlarından birisi de fiziksel egzersizin beyin ve sinir gelişiminde merkezi rol oynadığıdır (Fabri ve Fortuna, 2020). Montessori hareket ve zihin ilişkisine dikkat çekerek, özellikle erken çocukluk döneminde hareketin doğasının yanlış anlaşıldığını, okullarda hareketin ihmal edildiğini, oysaki hareketin gelişen zihinle yakın ilişkili olduğunu belirtmiştir (Montessori, 2015, s. 155). Günlük aktivitelerde egzersizlere yer verilerek kas gelişiminin de desteklenmesi sağlanmıştır. Bunun yanı sıra kasların gelişimi günlük yaşam alıştırmaları, materyallerin taşınması, düzenlenmesi vb. yollarla desteklenmektedir (Lillard, 2013, s. 188). Çocuk on parçadan oluşan pembe kulenin her parçasını ayrı ayrı çalışma alanına taşırken hem hareket ihtiyacını gerçekleştirir hem de her parçanın özelliklerinin daha çok farkına varır.

Aynı zamanda duyu ve hareketlerin ilişki olduğunu savunan Montessori, duyu ve hareket etkinliğini “ilişki sistemleri” ve "çevre ile bir bağ oluşturan düğüm noktaları” olarak tanımlamaktadır. Ona göre çocuğun psişik-zihinsel ve sosyal gelişiminin temelinde hareket ve duyu etkinliğinin birliği yer almaktadır (Çakıroğlu Wilbrandt, 2019, s. 54).

Egzersizin beyin gelişiminde önemli bir faktör olduğu, motor sistem ile bilişsel sistemin ilişkili olduğu çeşitli araştırmalarla da vurgulanmaktadır. Aerobik ve diğer tip egzersizlerin beyinde sinir dokusu oluşumunu uyardığı hatta yetişkin ve yaşlılarda lif 
miyelinasyonunu geliştirdiği, düzenli egzersizin, ruh halini iyileştirmenin yanı sıra, bilişsel yetenek, hafıza, genel plastisite ve gri madde hacmini artırarak beyinsel fonksiyonları geliştirdiği görülmektedir (Fabri ve Fortuna, 2020).

Eskiden, beynin kafada bedenin de kafanın aşağısında yer alması gibi basit bir gerekçe ile beyin ve bedenin birbirinden ayrı olduğu görüşü hâkimdi. Beden- zihin ilişkisinin ilk kanıtları 1996 yılında Stanford Üniversitesinde sinirbilimci olarak çalışan Henrietta ve Alan Leiner tarafindan ortaya konulmuştur (Jensen, 2006, s. 83).

Devinimsel gelişim ve öğrenme arasında ilişki olduğunu destekleyen birçok araştırma bulunmaktadır. Anteriror cingulate olarak bilinen bölge, yeni hareket veya hareketler kombinasyonu olduğunda etkinleşmektedir. Bu özel bölgenin hareketi öğrenmeyle birleştirdiği düşünülmektedir. Egzersizin beynin ürettiği önemli bir madde olan, nöral yenilenme ve plastisitede önemli bir rol oynayan BDNE'nin salgılanmasını harekete geçirdiği belirtilmektedir. Bu özel madde, nöronların birbirleri ile bağlanma ihtimalini arttırarak, bilişin güçlenmesini sağlamaktadır. Sedanter veya durağan yaşam biçiminin söz konusu maddenin sentezlenmesini geciktirdiği, akademik başarı ve öğrenmede olumsuz etkilere neden olduğu görülmüştür. Ayrıca beyin, hareket ve öğrenme arasında oldukça önemli bir ilişki olduğu, hareketin öğrenme süreçleri için hayati önem taşıyan nörobiyolojik mekanizmaların işlerliğini ve etkinliğini arttırdığına da dikkat çekilmektedir. Son yıllarda yapılan araştırmalarda, değişik yaş grubundaki öğrencilerin akademik başarı ve becerilerinin düşük olmasının en büyük sebebinin sedanter yaşam olduğu, 21. Yüzyılın en büyük problemlerinden birinin durağan, hareketsiz yaşam tarzı olduğu belirtilmektedir (Demir vd. 2016; Jensen, 2006, s. 84-88). Hareketin içeriği ve sıklığına göre beyin üzerindeki etkileri değişebilmektedir. Özdoğru, Kaya ve Yertutanol (2018), son 15 yılda yayınlanmış olan araştırmaları incelediklerinde düzenli bir şekilde yapılan aerobik egzersizin, çocuk ve ergenlerin konsantrasyon, dikkat, bellek, bilişsel kontrol, plan, tepki kararlığı gibi bir takım yürütücü işlevleri daha iyi yapabilmelerinde etkili olduğunu tespit etmişlerdir. Dil ve matematik gibi derslerde ve genel zekâ testlerindeki puan artışı ile bilişsel gelişimin de aerobik egzersizden olumlu yönde etkilendiği görülmüştür. Bununla birlikte egzersizin erken çocuklukta olduğu gibi yaşlı bireylerde de beyin plastisitesini, duyuşsal işlevleri ve bilişselliği olumlu yönde 
etkilediği belirtilmektedir (Ericson, Gildengers \& Butters, 2013). Hareketin, kardiyovasküler sistemin iyileştirilmesinden, kas sistemlerinin, metabolik dengenin sağlanmasına ve organ sistemlerinin gelişimine kadar insan vücudu için önemli olduğu bununla birlikte beynin de hafıza, zekâ gibi birçok alanda hem yapısal hem de işlevsel olarak hareketten büyük oranda etkilendiği görülmektedir (de Giorgio, Kuvacic, Milic \& Padulo, 2018).

Montessori, beden-zihin ilişkisini kendi uygulama ve gözlemlerine dayanarak keşfetmiş ve eğitim sisteminde motor gelişimi ile zihin gelişimini desteklemeye yönelik birçok uygulamaya yer vermiştir. Nörobilimsel araştırma sonuçlarında da görüldüğü gibi bedensel hareketler ve etkinlikler çocuklarda metabolik dengenin sağlanması kadar zihin gelişimi açısından da önemlidir. Bu noktada Montessori’nin beden zihin etkileşimi vurgusu nörobilimsel olarak da destek bulmaktadır.

\section{SONUÇ ve ÖNERÍLER}

Montessor'nin yaşadığı dönemde eğitim felsefesi bazı eğitimciler tarafindan dönemin koşullarına göre makul ve doğal karşılanmasa da günümüzde insana ait gen haritalarının çözülmesi ile birlikte onun yüz yıl önce çocuklara ilişkin savunduğu fikirlerinin bugün artık farklı disiplinler ile de kanıtlandığının söylenmesi mümkündür (Çakıroğlu Wilbrandt, 2019). Montessori, erken çocuklukta hassas dönemlere, duyuların eğitimine, yapılandırılmış ortamın ve doğal tekrarların öğrenme açısından önemine dikkat çekmiş ve böylece beyinde plastisiteyi işaret etmiştir. Beyinde dil ile ilgili mekanizmalar olduğunu ve çocukların doğal ortamları içinde dili öğrendiklerini savunmuştur. Egzersiz ve hareketin sağlıklı bir zihin gelişiminde temel oluşturduğunun önemini fark etmiştir. Tüm bu boyutlarıyla düşünüldüğünde bu model mevcut nörobilim süreçlerinin anlaşılması için uygundur. Çünkü bu özelliklerin temelinde Montessori’nin tıp geçmişi, araştırmaları, gözlem ve uygulamaları yatmaktadır (Catherine, Javier ve Francisco, 2020; Fabri ve Fortuna, 2020). Bu durum yaklaşımın günümüzde hala etkisinin devam etme nedenini de açıklamaktadır. 
Montessori’nin eserlerinde tırnak içinde yer verdiği "yöntem" kelimesi bir kişinin görüşlerini değil, çocukları gözlemlemeye dayalı bilimsel bakışı temel alır. Dolayısıyla öğretmenler de bilim insanı olarak her düzeydeki çocuklarla yaptıkları gözlemlerde aslında deneyler yapmaktadırlar. Eğitimcilerin ilk olarak unutmamaları gereken şey şudur: Montessori de eğitim uygulamalarına başladığında neyi keşfedeceğini bilmiyordu, eğitimciler de öyle. Bu nedenle eğitimcilerin her çocuğu incelemek ve keşfetmek için gözlem yapmaları önemlidir. Çocukların doğasını keşfetmenin ve çalışmanın tek yolu gözlemdir (Sackett, 2016). Eğitimciler sınıflarında iyi birer gözlemci ve bilim insanı olmalıdırlar. Gözlemlerini kaydederek, çocukların ilgi ve ihtiyaçlarını gerçekleştirebilecekleri ortamı oluşturmaya çalışmalıdırlar. Çünkü ancak bu bakış açısıyla bakıldığında çocukların gelişimi, öğrenmeleri için en uygun ortam ve imkânlar sunulabilir ve çocuklar tam anlamıyla desteklenebilir.

Araştırma bulguları beyinin etkin kullanımı için duyularla, özel materyallerle ve tekrarlarla öğrenmeye, öğrenmede hareketi kullanmaya, kritik dönemlerin ve dilin önemine dikkat çekmektedir. Bugün de karşımıza çıkan STEAM gibi yaklaşımlar hem etkin öğrenmeyi hem de farklı disiplinleri bir araya getirmeyi hedeflemektedir. Bu bağlamda eğitimcilerin duyularla ve tekrarlarla öğrenme, eğitim ortamı düzenleme, kritik dönemler ve dil zihin, hareket zihin ilişkisine yönelik farkındalıkları seminerlerle artırılabilir. Montessori yönteminden uygulama örnekleri sunularak kendi koşullarına uygun, çocukların beyin gelişimlerini destekleyecek ortam, materyal ve etkinlik hazırlamalarında rehberlik sağlanabilir. Programın yürütülmesinde farklı disiplinler ile işbirliği yapmaları için eğitimcilere disiplinlerarası uygulama örnekleri sunulabilir.

Yapılan doküman analizi sonucunda Montessori Yöntemi ile nörobilimsel çalışmaların ilişkilendirildiği yurtdışında yapılmış olan 3 adet çalışmaya ulaşılmıştır. Bu durum ilgili araştırma alanının son dönemlerde gündeme gelen güncel bir konu olduğunu göstermektedir. $\mathrm{Bu}$ nedenle üzerinde daha fazla ve daha kapsamlı araştırmalar yapılmasının önemli olduğu düşünülmektedir. Bu araştırmada, Montessori yönteminde vurgulanan temel özelliklerden yola çıkılmış ve bu özellikleri vurgulayan nörobilimsel çalışmaların incelenmesine çalışılmıştır. Sonraki araştırmalarda Montessori yönteminin 
farklı özelikleri incelenebilir. Çalışma doküman analizi ile sınırlı olduğundan gözleme veya deneye dayalı araştırmalar yapılarak karşılaştırmalı bulgular elde edilebilir. 


\section{KAYNAKLAR}

Acay, E. (2018). Okul öncesi çocuklarının renk ve doku bilgilerini edinmelerine montessori eğitim yönteminin etkililiği. Yüksek Lisans Tezi. Necmettin Erbakan Üniversitesi Eğitim Bilimleri Enstitüsü, Konya.

Akdağ, F. (2015). Çocukta beyin gelişimi ve erken müdahale.Hacettepe University Faculty of Health Sciences Journal, 1(2), 97-100.

Arechavala-Lopez, P., Diaz-Gil, C., Saraiva, J. L., Moranta, D., Castanheira, M. F., Nuñez-Velázquez, S., et al. (2020). Effects of structural environmental enrichment on welfare of juvenile seabream (Sparus aurata). Aquac. Rep. 15:100224. https://doi.org/10.1038/s41598-020-68306-6

Barker, J.E., Semenov, A.D., Michaelson, L., Provan, L.S., Snyder, H.R., Munakata, Y. (2014). Less-structured time in children's daily lives predicts self-directed executive functioning. Frontiers in Psychology, 5, 1-16. https://doi.org/10.3389/fpsyg.2014.00593

Benic, M.Z., Jambresic, I. (2020). Is there a need for handicraft in preschool? attıtudes of preschool teachers and parents on including handicraft activities in the regular preschool program. Proceedings Of 14th International Technology, Education And Development Conference (Inted2020), 1511-1519.

Bezirci, H. (2017). Montessori yönteminin anaokulu çocukların akran ilişsilerine ve akran tepkilerine etkisinin incelenmesi. Yüksek Lisans Tezi. Selçuk Üniversitesi Sosyal Bilimler Enstitüsü, Konya.

Bülgür, N. (2018). Montessori eğitiminin 5-6 yaş grubu çocukların yalnızlı ve sosyal memnuniyetsizlik düzeyleri üzerindeki etkisi (Adana ili örneği). Çağ Üniversitesi Sosyal Bilimler Enstitüsü, Mersin.

Campbell,S.R. (2011). Educational neuroscience: motivations, methodology, and implications, Educational Philosophy and Theory, 43(1), 7-16. https://doi.org/10.1111/j.1469-5812.2010.00701.x

Canbulat, Zengin, İ. (2019). 5-6 yaş çocukların matematik becerilerinin geliștirilmesinde Montessori eğitim programının etkisi. Yüksek Lisans Tezi. Yeditepe Üniversitesi Eğitim Bilimleri Enstitüsü, İstanbul.

Casey, B.J., Tottenham, N., Liston, C. \& Durston, S. (2005). Imaging the developing brain: what have we learned about cognitive development?. TRENDS in Cognitive Sciences, 9(3), 104-110. https://doi.org/10.1016/j.tics.2005.01.011

Catherine, L., Javier, B. and Francisco, G. (2020), Four Pillars of the Montessori Method and Their Support by Current Neuroscience. Mind, Brain, and Education. http://dx.doi.org/10.1111/mbe.12262 
Çakıroğlu Wilbrandt, E. (2019) Montessori yöntemi: her yönüyle montessori eğitimi ve etkinlik rehberi. İstanbul: Final.

Davis, E.P., Stout, S.A., Molet, J., Vegetabile, B., Glynn, L.M., Sandman, C.A., Heins, K., Stern, H. \& Baram, T.Z. (2017). Exposure to unpredictable maternal sensory signals influences cognitive development across species. PNAS, 114(39), 10390-10395. www.pnas.org/cgi/doi/10.1073/pnas.1703444114

de Giorgio, A., Kuvacic, G., Milic, M. \& Padulo, J. (2018). The brain and movement: how physical activity affects the brain. Monten. J. Sports Sci. Med., 7, 63-68. https://doi.org/10.26773/mjssm.180910

Dedeoğlu, S. (2018). MEB okul öncesi eğitim programı ve Montessori programına göre eğitim alan çocukların bilişsel gelişim ve sosyal yetkinliklerinin karşılaştırmalı olarak incelenmesi. Yüksek Lisans Tezi. Necmettin Erbakan Üniversitesi Eğitim Bilimleri Enstitüsü, Konya.

Demir, M.Ş., Usta, M.E., Yayla, A., Taşkın, N., Hastunç, Y., Alav, Ö. (2016). Çeşitli nöro-bilişsel \& nöro-pedagojik uygulama ve modalitelerin bilişsel becerilerin gelişimi üzerindeki etkisi. Ahi Evran Üniversitesi Kırşehir Eğitim Fakültesi Dergisi (KEFAD), 17(2), 679-696.

Diamond, M.C. (2001). Response of the brain to enrichment. An. Acad. Bras. Cienc., 73(2), 211-220.

Dinçer Yavuz, İ. (2019). Okul öncesi dönemde montessori yöntemi ile veya geleneksel yöntem ile eğitim alan çocukların okul olgunluğu düzeyleri, öz düzenleme becerileri ve annelerinin çocuklarının yeteneklerine ilişkin algıları. Yüksek Lisans Tezi. Ufuk Üniversitesi Sosyal Bilimler Enstitüsü, Ankara.

Dronkers, N.F., Wilkins, D.P., Van Valin, R.D., Redfern, B.B., Jaeger, J.J. (2004). Lesion analysis of the brain areas involvedin language comprehension. Cognition, 92, 145-177. http://dx.doi.org/10.1016/j.cognition.2003.11.002

Durkaya, S. (2019). Meb okul öncesi eğitim programına ve montessori yaklaşımına göre eğitim alan anasınıfi çocuklarının sezgisel matematik yeteneklerinin karşılaştırılması. Yüksek Lisans Tezi. Marmara Üniversitesi Eğitim Bilimleri Enstitüsü, İstanbul.

Ergenç, İ.(2008). Dilin Beyindeki Gerçekleşimi ve Konuşma Eylemi. S. Karakaş (Ed.), Kognitif Neurobilimler (s. 169-185). Ankara: Nobel Tip Kitabevi.

Ericson, K.I., Gildengers, A.G. \& Butters, M.A. (2013). Physical activity and brain plasticity in late adulthood. Dialogues in Clinical Neuroscience, 15(1), 99-108.

Fabri, M. \& Fortuna, S. (2020). Maria montessori and neuroscience: the trailblazing 1nsights of an exceptional mind. The Neuroscientist ,26(5-6), 394-401. https://doi.org/10.1177/1073858420902677

Friederici, A.D. (2006). The neural basis of language development and its impairment. Neuron 52, 941-952. https://doi.org/10.1016/j.neuron.2006.12.002 
Friederici, A.D., Chomsky, N., Berwick, R.C., Moro, A. \& Bolhuis, J.J. (2017). Language, mind and brain. Nature Human Behaviour, 1, 713-722. . https://doi.org/10.1038/s41562-017-0184-4

Gabard-Durnam, L., McLaughlin, K.A. (2020). Sensitive periods in human development: charting a course for the future. Current Opinion in Behavioral Sciences. 36, 120-128. https://doi.org/10.1016/j.cobeha.2020.09.003

Gopalakrishnan,B., Karpagam, K., Selvaraj, K. (2020). Effectiveness of sensory stimulation on sensory function among patients with stroke. International Journal of Research in Pharmaceutical Sciences, 11, 96-99. https://doi.org/10.26452/ijrps.v11iSPL4.3746

Goswami, U. (2004). Annuel review: Neuroscience and education. British Journal of Educational Psychology, 74, 1-14. http://dx.doi.org/10.1348/000709904322848798

Goswami, U.(2011). Principles of learning, 1mplications for teaching: a cognitive neuroscience perspective. Journal of Philosophy of Education 42(3 - 4):381 399. https://doi.org/10.1111/j.1467-9752.2008.00639.x

Greenough, W.T. (2002). Brain adaptation to experience:an uptade. In M.H. Jhanson, Y. Munaka \& RR.O. Gilmore (Eds.), Brain development and cognition a reader: second edition (pp. 213-216). USA: Blackwell.

Greenough, W.T., Black,J.E. \& Wallace, C.S. (2002). Experience and brain development. In M.H. Jhanson, Y. Munaka \& RR.O. Gilmore (Eds.), Brain development and cognition a reader: second edition (pp.186-213). USA: Blackwell.

Grossman, A.W., Churchill, J.D., McKinney, B.C., Kodish, I.M., Otte, S.L., Greenough, T.G. (2003). Experience ejects on brain development: possible contributions to psychopathology. Journal of Child Psychology and Psychiatry, 44(1), 33-63.

Hensch, T.K. (2005). Critical Period mechanisms in developing visual cortex. Current Topics in Developmental Biology, 69, 215-237. https://doi.org/10.1016/S00702153(05)69008-4

Jensen, E. (2006). Beyin uyumlu öğrenme (A. Doğanay Çev.). Adana: Nobel.

Jones, W. P. (2005). Music, the brain, and education. Montessori Life: A Publication of the American Montessori Society, 17(3), 40-45.

Karasar, N. (2005). Bilimsel araştırma yöntemi. Ankara: Nobel.

Keleş, E., Çepni, S. (2006). Beyin ve öğrenme. Türk Fen Eğitimi Dergisi,3(2), 66-82.

Kınık, B. (2018). Montessori temelli bireysel eğitim programının özel eğitim gereksinimi olan çocukların problem çözme becerilerine etkisinin incelenmesi. Yüksek Lisans Tezi. Abant İzzet Baysal Üniversitesi Eğitim Bilimleri Enstitüsü, Bolu. 
Kuhl, P. K. \& Rivera-Gaxiola, M. (2008). Neural substrates of early language acquisition. Annu. Rev. Neurosci. 31, 511-534.

https://doi.org/10.1146/annurev.neuro.30.051606.094321

Lamrani, R., Abdelwahed, E. (2020). Game-based learning and Gamification to improve skills in early years education. Computer Sclence and Informatıon Systems, 17(1), 339-356. https://doi.org/10.2298/CSIS190511043L

Lamrani, R., Abdelwahed, E., Chraibi, S., Qassimi, S., Hafidi, M. (2018). Gamification and serious games based learning for early childhood in rural areas. Challenges, 11(31), https://doi.org/10.3390/challe11020031

Lillard, A.S. (2020). Montessori as an alternative early childhood education. Early Child Development and Care, 1-11. https://doi.org/10.1080/03004430.2020.1832998

Lillard, P.P. (2013). Montessori modern bir yaklaşım (O. Güngüz Çev.). Ankara: Kaknüs.

Lillard, P.P. (2014). İlk ve ortaokulda Montessori eğitimi (O. Gündüz Çev.). Ankara: Kaknüs.

Lillard, A. S., Heise, M. J., Richey, E. M., Tong, X., Hard, A. \& Bray, P. M. (2017). Montessori preschool elevates and equalizes child outcomes: A longitudinal study. Frontiers in Psychology, 8, 1-19. https://doi.org/10.3389/fpsyg.2017.01783

Liston, D. (1995, April). Basic guidelines for brain-compatible classrooms: theory to praxis. Paper Presented at the Annual Meeting of the American Educational Research Association, San Francisco, CA.

Lopata, C., Wallace, N. \& Finn, K. (2005). Comparison of academic achievement between Montessori and traditional educational programs. Journal of Research in Childhood Education, 20(1), 5-13.

Lores-Arnaiz S., Bustamante J., Czerniczyniec A., Galeano P., Gonzalez Gervasoni M., Rodil Martínez A., Paglia N., Cores V., Lores Arnaiz M.R. (2007). Exposure to enriched environments significantly increases brain nitric oxide synthase and improves cognitive performance in pre-pubertal but not in young rats. Behavioural Brain Research, 184,117-123. https://doi.org/10.1016/j.bbr.2007.06.024

Mavrelos, M., Daradoumis, T. (2020). Exploring multiple intelligence theory prospects as a vehicle for discovering the relationship of neuroeducation with 1maginative/waldorf pedagogy: a systematic literature review. Education Sc1ences, 10(11), 1-26. https://doi.org/ 10.3390/educsci10110334

Moher D, Liberati A, Tetzlaff J, Altman DG, The PRISMA Group (2009) Preferred Reporting Items for Systematic Reviews and Meta-Analyses: The PRISMA 
Statement. PLoS Med 6(7): e1000097.

https://doi.org/10.1371/journal.pmed.1000097

Montessori, M. (2015). Emici zihin (O. Gündüz Çev.). Ankara: Kaknüs.

Montessori, M. (2016). Çocuğun keşfi (O. Gündüz Çev.). İstanbul: Kaknüs.

Nabar, M.J.M.Y., Algieri, R.D., Tornese, E.B., Ferrante, M.S., Broffman, C. \& Algieri, A. (2020). Playbased learning in anatomy: impact on cultural conceptions and cadaveric affronting from cognitive neuroscience. Internatıonal Journal of Morphology, 38(4), 1065-1073.

National Scientific Council on the Developing Child. (2007). The timing and quality of early experiences combine to shape brain architecture. Cambridge, MA:National Scientific Council on the Developing Child; Working Paper No.5 http://developingchild.harvard.edu/library/reports_and_working_papers/wp5/

Nithianantharajah, J., Hannan, A.J. (2006). Enriched environments, experiencedependent plasticity and disorders of the nervous system. Nature reviews Neuroscience, 7, 607-709.

Noyat, Ş. (2018). Görsel sanatlar ĕgitiminde Montessori ĕgitimi yaklaşımının, okul öncesi çocuklarının yaratıcılık gelişimlerine etkisi. Yüksek Lisans Tezi. Ondokuz Mayıs Üniversitesi Eğitim Bilimleri Enstitüsü, Samsun

Nutbrown, C. (2005). Key Concepts in early childhood education and care. California: Sage.

Oğuz, V., Köksal Akyol, A. (2006). Çocuk eğitiminde montessori yaklaşımı. Ç.Ü.

Sosyal Bilimler Enstitüsü Dergisi, 15(1), 243-256.

Olson, M.H. \& Hergenhahn B.R. (2016). Öğrenmenin kuramlart-theories of learning(S. Temizel Çev.). Ankara: Nobel.

Onan, B: (2010). Beynin bilişsel işlevleri üzerine yapılan araştırmalar ve ana dili eğitimine yansımaları. Türklük Bilimi Araştırmaları, 27, 521-561. https://dergipark.org.tr/tr/pub/tubar/issue/16968/177247 adresinden erişilmiştir.

Özdoğru, A.A., Kaya Yertutanol, F.D. (2018). Çocuk ve ergenlerin nörobilişsel gelişimlerinde aerobik egzersizin etkileri. Çocuk ve Gençlik Ruh Să̆lı̆̆l Dergisi, 25 (2), 165-174.

Pollard, M. (1996). Maria Montessori Dünya'daki ĕgitim sisteminde devrim yapan Italyan doktor (L. Onat Çev.).Ankara: İlk Kaynak.

Poussin, C. (2015). Bana kendi kendime yetmeyi öğret anne babalar için Montessori pedagoji. (B. Şaman Çev.) Ankara: Kaknüs.

Reh, R.K., Dias, B.G., Nelsonn, C.A., Kaufer, D., Werker, J.F., Kolb, B., Levine, J.D. \& Hensch, T.K. (2020). Criticalperiodregulation acrossmultipletimescales. Proceedings of the National Academy of Sciences 117(38). https://doi.org/10.1073/pnas.1820836117 
Rosenberg-Lee, M. (2018). Training Studies: An experimental design to advance educational neuroscience. Mind, Brain, And Educatıon, 12(1), 12-22.

Sackett, G. (2016). The scientist in the classroom: the montessori teacher as scientist. The NAMTA Journal ,41(2), 5-20.

Smith, O. (2014). 10 Minutes of bliss. Montessori Life: A Publication of the American Montessori Society, 26(1), 48-50.

Şimşek, Y. (2018). Montessori yaklaşımı ile verilen beslenme eğitiminin 4-5 yaş çocukların besin grupları bilgisi, beslenme alışkanlıkları ve sofra düzeni bilgisi üzerine etkisinin incelenmesi. Yüksek Lisans Tezi. Necmettin Erbakan Üniversitesi Eğitim Bilimleri Enstitüsü, Konya.

Temel, F. (1994). Montessori'nin görüşleri ve eğitime yaklaşımı. Okul Öncesi Ĕ̆itimi Dergisi, 47(1), 18-22.

Tomele, G., Lidaka, A. (2017). The use of Montessori pedagogy in children's speech and language development promotion. Proceedings of $3 \mathrm{rd}$ International Conference On Lifelong Learing And Leadersip For All (Iclel 2017), 706-715.

Tottenham, N. (2014). The importance of early experiences for neuro-affective development. Current Topics in Behavioral Neurosciences, 16, 109-129. https://doi.org/10.1007/7854_2013_254

Üstündağ, K. (2019). Montessori yönteminin okul öncesi dönemdeki çocukların bilimsel süreç becerilerine etkisinin incelenmesi. Yüksek Lisans Tezi. Necmettin Erbakan Üniversitesi Eğitim Bilimleri Enstitüsü, Konya.

van der Meulen, A., Krabbendam, L. \& de Ruyter, D. (2015). Educational neuroscience: 1ts position, aims and expectations, British Journal of Educational Studies, 63(2), 229-243. https://doi.org/10.1080/00071005.2015.1036836

van Dijk, W. \& Lane, H.B. (2020) The brain and the US education system: perpetuation of neuromyths, Exceptionality, 28(1), 16-29. https://doi.org/10.1080/09362835.2018.1480954

Viru, A., Loko, J., Harro, M., Volver, A., Laaneots, L., Viru, M. (1999). Critical periods in the development of performance capacity during childhood and adolescence. Eur. J. Phys. Educ. 4, 75-119. https://doi.org/10.1080/1740898990040106

Vries, G.J., Fields, C.T., Peters, N.V., Whylings, J. \& Paul, M.J. (2014). Sensitive periods for hormonal programming of the Brain. Current Topics in Behavioral Neurosciences, 16, 79-108. https://doi.org/10.1007/7854_2014_286

Yıldırım, A., Şimşek, H. (2016). Sosyal bilimlerde nitel araştırma yöntemleri. Ankara: Seçkin.

Yıldırım, C. (2019). Montessori yöntemine dayalı öğretim tasarımının birinci sınıf ögrencilerinin hazırbulunuşluklarına matematik ve okuma-yazma becerilerine etkisi. Doktora Tezi. Burdur Mehmet Akif Ersoy Üniversitesi Eğitim Bilimleri Enstitüsü, Burdur. 
Yıldırım, D., Çetingöz, D. (2017). Duyu eğitiminin otistik çocukların alıcı dil gelişimine etkileri. Kastamonu Ĕgitim Dergisi, 25(5), 1819-1834.

Yıldız, F. Ü. (2018). Montessori anne destek eğitim programının; Montessori ĕgitimi alan 4-5 yaş çocukların matematik ve günlük yaşam becerilerine etkilerinin incelenmesi. Doktora Tezi. Selçuk Üniversitesi Sosyal Bilimler Enstitüsü, Konya.

\section{ORCID}

Şeyma Sultan Bozkurt (D) https://orcid.org/0000-0002-4579-1542

İlkay Ulutaş https://orcid.org/0000-0002-2234-0773 


\section{SUMMARY}

\section{Purpose}

Having critical importance in the development of children in the early years in the Montessori philosophy; features such as sensitive periods, absorbing mind, sensory training, prepared environment, spontaneous learning with repetitions, language-brain, a movement-brain relationship is emphasized. Since these features explain the development and learning of the child, they are also emphasized in terms of neuroscience. In the period when detailed discoveries regarding these issues have not yet been made in neuroscience, Montessori designed and implemented an educational method based on these features. (Catherine, Javier ve Francisco, 2020; Fabri ve Fotuna, 2020; Sackett, 2016). Therefore, it is thought that the Montessori method will have strong connections in terms of the Brain. In this direction, the study aimed to explain the basic features of the Montessori education method with a neuroscientific perspective, based on the question "Which features of the Montessori Method are supported by discoveries about the brain and learning made in the field of neuroscience", and to reveal an interdisciplinary perspective by examining the studies that associate Montessori and neuroscience.

\section{Method}

This research was planned as a compilation, and it was attempted to clarify the subject by accessing and analyzing the sources including Montessori and neuroscience relationship. Document analysis technique was used in accessing and analyzing the research. Document analysis is the analysis of information written materials about the topic or facts to be investigated (Yuldirım ve Şimşek, 2016, s.189). The literature review was carried out in two stages. In the first stage, the sources directly associated with the Montessori method and neuroscience were scanned and the associated basic features were determined. In the second screening study, studies in both disciplines were examined according to the characteristics determined.

\section{Findings}

As a result of the first screening study, three studies conducted in 2020, in which neuroscientific studies were examined with the Montessori Method, were reached. These studies were analyzed according to the topics related to the Montessori method and neuroscientific studies. As a result of the analysis, it was seen that the basic features of "Sensitive Periods", "Structured Environment", "Sensory Education", " Spontaneous Learning with Repetitions ", "LanguageBrain" and "Movement-Brain" in the Montessori method were examined and discussed within the scope of neuroscientific research.

In the second screening study, after determining the features of Montessori education addressed in neuroscientific research, a total of 37 resources, 26 articles, and 11 books, published between 1994-2020, were examined in the literature review in line with these features.

\section{Result and Conclusion}

As a result of the research, it was seen that when the basic features related to the Montessori method and neuroscience were examined in line with the studies conducted in both fields, findings 
that support each other were reached. It has been observed that the research results in the neuroscientific field on sensitive periods (Gabard-Durnam ve McLaughlin, 2020; Greenough, Black \& Wallace, 2002, s. 186; Hensch, 2005; Reh vd., 2020; Vries, Fields, Peters, Whylings \& Paul, 2014; Viru vd., 1999), structured / enriched environment (Arechavala-Lopez vd., 2020; Diamond, 2001; Gabard-Durnam ve McLaughlin, 2020; Jensen, 2006; Lores-Arnaiz vd., 2007; Nithianantharajah ve Hannan, 2006; Vries, Fields, Peters, Whylings \& Paul, 2014), sensory training (Casey, Tottenham, Liston \& Durston, 2005; Gopalakrishnan, Karpagam, Selvaraj, 2020), spontaneous learning with repetitions (Barker vd., 2014; Greenough, 2002; Greenough, Black \& Wallace, 2002; Olson \& Hergenhahn, 2016; Tottenham, 2014), language development (Ergenç, 2008; Friederici, 2006; Friederici, Chomsky, Berwick, Moro \& Bolhuis, 2017; Kuhl \& Rivera-Gaxiola, 2008; Tomele ve Lidaka, 2017) and movement-brain relation (de Giorgio, Kuvacic, Milic \& Padulo, 2018; Demir vd. 2016; Ericson, Gildengers \& Butters, 2013; Jensen, 2006; Özdoğru, Kaya ve Yertutanol, 2018) support Montessori's thoughts and discoveries. Considering all these dimensions, this model is suitable for understanding processes. Because based on these features are Montessori's medical history, researches, observations, and practices (Catherine, Javier ve Francisco, 2020; Fabri ve Fortuna, 2020). This situation explains the reason why the effect of the approach continues today. 